\title{
South African EUCAARI measurements: seasonal variation of trace gases and aerosol optical properties
}

\author{
L. Laakso ${ }^{1,2,9}$, V. Vakkari ${ }^{2}$, A. Virkkula ${ }^{2}$, H. Laakso ${ }^{2}$, J. Backman ${ }^{2}$, M. Kulmala ${ }^{2}$, J. P. Beukes ${ }^{1}$, P. G. van Zyl ${ }^{1}$, \\ P. Tiitta ${ }^{1}$, M. Josipovic ${ }^{1}$, J. J. Pienaar ${ }^{1}$, K. Chiloane ${ }^{3}$, S. Gilardoni ${ }^{4}$, E. Vignati ${ }^{4}$, A. Wiedensohler ${ }^{5}$, T. Tuch ${ }^{5}$, \\ W. Birmili ${ }^{5}$, S. Piketh ${ }^{6}$, K. Collett ${ }^{6}$, G. D. Fourie ${ }^{7}$, M. Komppula ${ }^{8}$, H. Lihavainen ${ }^{9}$, G. de Leeuw ${ }^{9,10}$, and \\ V.-M. Kerminen ${ }^{2,9}$ \\ ${ }^{1}$ School of Physical and Chemical Sciences, North-West University, Potchefstroom, South Africa \\ ${ }^{2}$ Department of Physics, University of Helsinki, Finland \\ ${ }^{3}$ ESKOM, Sustainability and Innovation, Environmental Sciences Department, South Africa \\ ${ }^{4}$ Climate Change Unit, European Commission DG JRC, Ispra, Italy \\ ${ }^{5}$ Leibniz Institute for Tropospheric Research, Leipzig, Germany \\ ${ }^{6}$ Climatology Research Group, University of the Witwatersrand, Johannesburg, South Africa \\ ${ }^{7}$ Sasol Technology, Research and Development, Sasolburg, South Africa \\ ${ }^{8}$ Finnish Meteorological Institute, Kuopio, Finland \\ ${ }^{9}$ Finnish Meteorological Institute, Helsinki, Finland \\ ${ }^{10} \mathrm{TNO}$, Utrecht, The Netherlands
}

Correspondence to: L. Laakso (lauri.laakso@fmi.fi)

Received: 2 July 2010 - Published in Atmos. Chem. Phys. Discuss.: 17 December 2010

Revised: 28 September 2011 - Accepted: 7 February 2012 - Published: 17 February 2012

\begin{abstract}
In this paper we introduce new in situ observations of atmospheric aerosols, especially chemical composition, physical and optical properties, on the eastern brink of the heavily polluted Highveld area in South Africa. During the observation period between 11 February 2009 and 31 January 2011, the mean particle number concentration (size range $10-840 \mathrm{~nm}$ ) was $6310 \mathrm{~cm}^{-3}$ and the estimated volume of sub- $10 \mu \mathrm{m}$ particles $9.3 \mu \mathrm{m}^{3} \mathrm{~m}^{-3}$. The aerosol absorption and scattering coefficients at $637 \mathrm{~nm}$ were $8.3 \mathrm{Mm}^{-1}$ and $49.5 \mathrm{Mm}^{-1}$, respectively. The mean single-scattering albedo at $637 \mathrm{~nm}$ was 0.84 and the Ångström exponent of scattering was 1.5 over the wavelength range $450-635 \mathrm{~nm}$. The mean $\mathrm{O}_{3}, \mathrm{SO}_{2}, \mathrm{NO}_{\mathrm{x}}$ and $\mathrm{H}_{2} \mathrm{~S}$-concentrations were $37.1,11.5,15.1$ and $3.2 \mathrm{ppb}$, respectively. The observed range of concentrations was large and attributed to the seasonal variation of sources and regional meteorological effects, especially the anticyclonic re-circulation and strong winter-time inversions. In a global context, the levels of gases and particulates were typical for continental sites with strong anthropogenic influence, but clearly lower than the most polluted areas of southeastern Asia. Of all pollutants observed at the site, ozone is the most likely to have adverse environmental effects, as the concentrations were high also during the growing season. The measurements presented here will help to close existing
\end{abstract}

gaps in the ground-based global atmosphere observation system, since very little long-term data of this nature is available for southern Africa.

\section{Introduction}

The direct and indirect radiative effects of aerosol particles constitute the largest uncertainty in current radiative forcing estimates of the Earth's climatic system (Foster et al., 2007; Hansen et al., 2007). In order to reduce the uncertainties associated with atmospheric aerosols in climate systems, detailed information on the temporal and spatial variability of different aerosol properties is required. Such information can be obtained from a combination of model simulations, remote sensing and continuous in-situ aerosol measurements.

Over the continental Southern Hemisphere, excluding equatorial Amazonia (Guyon et al., 2003), long-term studies of atmospheric aerosols are limited compared to the vast area it covers (Jayaratne and Verma, 2001; Swap et al., 2003; Ross et al., 2003; Laakso et al., 2006; Suni et al., 2008; Rissler et al., 2006; Vakkari et al., 2011; Queface et al., 2011; Hirsikko et al., 2012; Venter al., 2012). On the African continent south of the equatorial region, number concentrations and 
especially optical properties of submicron aerosol particles have mainly been investigated during the SAFARI 1992 and SAFARI 2000 measurement campaigns (Swap et al., 2003; Ross et al., 2003; Eck et al., 2003). On a long-term basis, the South African Weather Service and NOAA-ESRL have conducted observations of aerosol number concentrations and optical properties such as light scattering and absorption as part of the Global Atmosphere Watch (GAW) program at the station in Cape Point (e.g. Brunke et al., 2010). However, at the time of writing, no publications on the aerosol measurements at Cape Point were available.

In general, these previous studies highlighted the importance of regional circulation, seasonal pollutant variation and multiple inversion layers (see also Garstang et al., 1996). The authors also pointed out that the atmospheric aerosol particle population originates from a mixture of natural and anthropogenic emission sources (e.g. domestic burning, wild fires, industry, etc.) and is spatially and temporally highly variable.

Recently, Vakkari et al. (2011) and Laakso et al. (2008, 2012) reported the annual trends of the sub-micron particle number concentration and associated new particle formation in a clean background savannah environment in South Africa, but these observations did not include measurements of aerosol optical properties. Long-term column aerosol optical properties have since been reported for a Zambian and South African sites (Queface et al., 2011). However, the need to improved data further remains, due to the spatial and temporal variability of different aerosol properties across the region.

The observations described in the present study took place on the Highveld in central South Africa. This area is among the top five $\mathrm{NO}_{2}$ emission hotspots in the world and is also a significant source of $\mathrm{CO}_{2}, \mathrm{SO}_{2}$ and sulphate particles (Held, 1996; Fleming and van der Merwe, 2004; Lourens et al., 2012).

The industrial emissions from this area, along with other regional emissions (especially from biomass burning) and intense solar radiation create a highly reactive pollution mixture (Swap et al., 2003). As a result, reactive gases are rapidly converted into more oxidized and low-volatile compounds that produce secondary aerosols via nucleation and condensation. These particles grow to accumulation mode sizes and mix with particles from primary emissions. Due to their long lifetime, these accumulation mode particles can be transported across the Indian Ocean, as far as Australia (Wenig et al., 2003), thereby affecting the radiative balance over large areas.

Due to its global importance, the Highveld was chosen as one of the EUCAARI project measurement areas outside Europe (Kulmala et al., 2009). The three other sites outside Europe were the Amazonian tropical forest near Manaus in Brazil, the suburban area near New Delhi in India, and the North China Plain near Beijing. These four sites comprise globally important regions with previously limited longterm aerosol measurements. At these four non-European
EUCAARI measurements sites, the scientific emphasis was placed on aerosol optical properties, direct aerosol effects, aerosol chemistry, and new particle formation at the surface. The final goal of these measurements was to obtain continuous long-term in situ data for validation and development of satellite products and global models. In South Africa, another specific interest was to stimulate improvement of the interpretation of remote sensing methods, as current approaches may not be valid due to the complex layered structure of the troposphere.

In this paper, results from EUCAARI measurements conducted in the Highveld area will be presented, along with a detailed description of the site, its regional characteristics, instrumentation and measurement procedures. The main purpose of this article is to provide a reference for future work, as well as analyze basic time series of trace gases and aerosol optical properties.

\section{Regional characteristics of the South African Highveld}

\subsection{Meteorology}

The meteorological situation in South Africa is subject to a strong seasonal variability. Above the central Highveld, the atmospheric circulation pattern is dominated by anticyclonic circulation during the winter and frequent easterly disturbances during the summer. Westerly disturbances take place approximately $20 \%$ of the time throughout the year (Garstang et al., 1996). The precipitation is characterized by strong seasonal variation with practically all precipitation falling during the wet season typically starting in October and ending in March. The precipitation cycle strongly affects local pollutant concentrations via primary emissions from wild fires during the dry season, as well as wet scavenging by precipitation and clouds during the wet season.

The cloud cover over the Highveld is often limited due to a dominant high pressure system, created by the high altitude and the subtropical subsidence (Tyson and Preston-Whyte, 2000). This, combined with low heat capacity of the soil, creates frequent inversions that significantly reduce the vertical mixing (Garstang et al., 1996). These inversions are most pronounced just before sunrise. In the presence of sunlight, the inversions begin to break down through convective heating and the height of the mixed layer is increased (Tyson et al., 1996; Tyson and Preston-Whyte, 2000).

The afore-mentioned meteorological conditions modulate the pollutant levels above the Highveld. With the high occurrence of anticyclonic circulations, pollutants can be trapped over southern Africa for several days before exiting the subcontinent, primarily towards the east coast via a well defined plume (Garstang et al., 1996; Freiman and Piketh, 2002; Piketh et al., 2000). Example of this circulation is visible in Fig. 1, which represents the statistical distribution of 


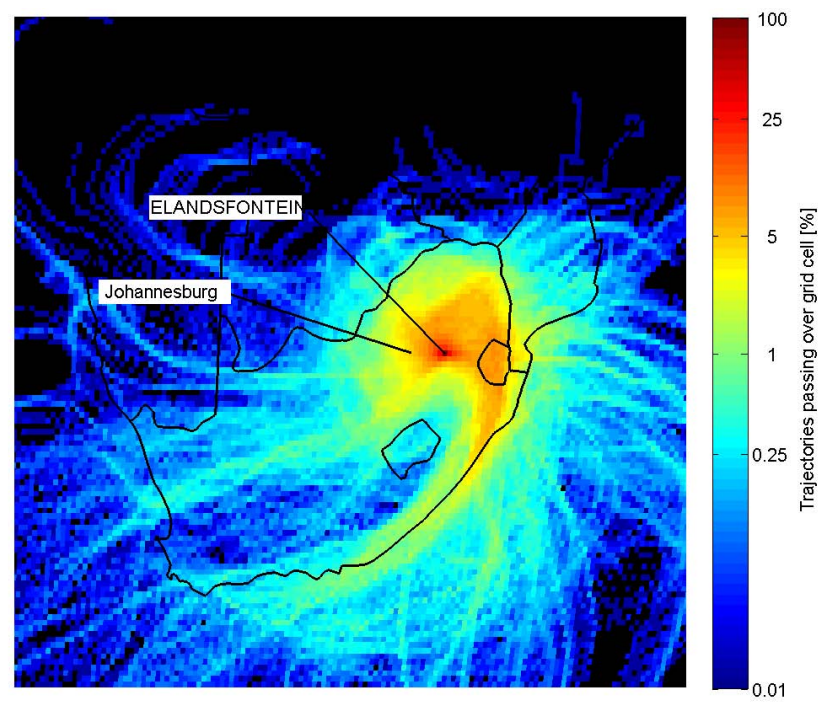

Fig. 1. Overlay back trajectory plot showing the percentage of trajectories arriving at Elandsfontein passing over specific areas for the period 11 February 2009-31 January 2011.

HYSPLIT 96-h back trajectories (Draxler and Hess, 2004) for the observational period of this paper.

Aerosol particles which are transported via this circulating pathway may also be trapped below stable layers found preferentially at $\sim 850 \mathrm{hPa}$ (over coastal regions), $\sim 700 \mathrm{hPa}$, $\sim 500 \mathrm{hPa}$ and $\sim 300 \mathrm{hPa}$ on no-rain days (Tyson and PrestonWhyte, 2000). The $500 \mathrm{hPa}$ layer is most persistent and usually caps pollutants in a haze layer over southern Africa. The layered structure is at its strongest during the dry and cold winter months.

\subsection{Emissions in the Highveld area}

Fig. 2 shows the 2010 population density estimate for southern Africa with a $0.25^{\circ} \times 0.25^{\circ}$ spatial resolution (CIESIN, 2010). The population density is an indicator of nonindustrial human activities, as well as the propitiousness of local ecosystem for human living.

Figure 3 shows the total emissions of $\mathrm{SO}_{2}$ based on the SAFARI 2000 emission inventory (Fleming and van der Merwe, 2004). The main point sources of pollutants in the Highveld are coal-fired power stations, petrochemical industry, as well as mining and metallurgical industries. The major pollutants released by these industries include $\mathrm{SO}_{2}, \mathrm{NO}_{\mathrm{x}}$ and particulate matter (PM), whilst the petrochemical industry additionally emits VOCs, $\mathrm{H}_{2} \mathrm{~S}$ and $\mathrm{NH}_{3}$ (Cardoso et al., 1997). During winter, a significant contribution of pollutants originates from domestic burning in informal settlements for cooking and space heating (June-August), as well as wild and managed fires (June-September). These emissions contain $\mathrm{NO}_{\mathrm{x}}, \mathrm{CO}$, VOCs and $\mathrm{PM}$, with significant contribution from black carbon. In addition, windblown dust from soil

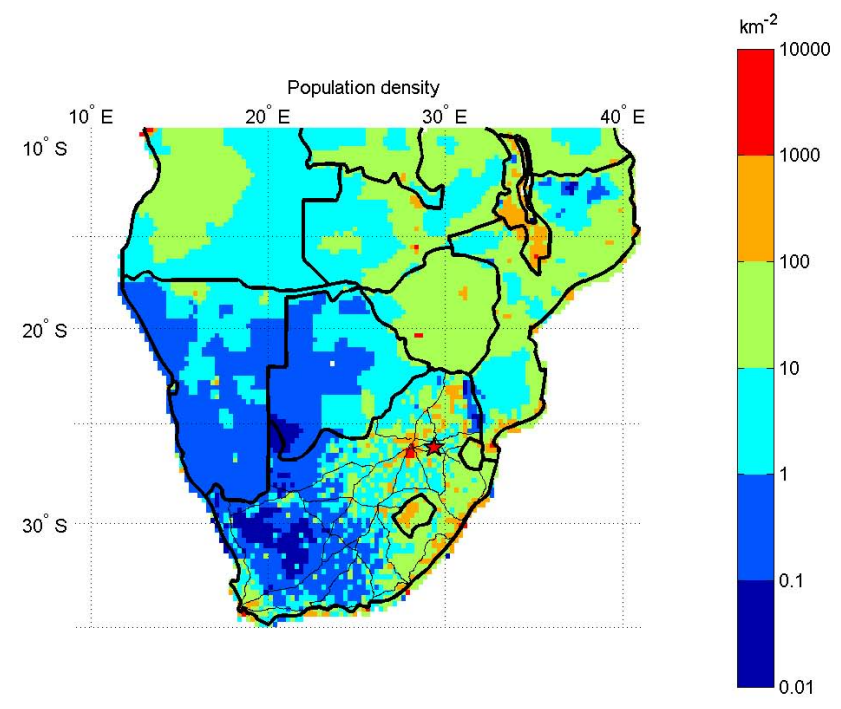

Fig. 2. Population density over southern Africa (CIESIN, 2010). In South Africa the main national roads are also shown. The measurement site is indicated with a red star. The population hot-spot west of the measurement site is the Gauteng metropolitan area consisting of Pretoria, Johannesburg and the Vaal Triangle.

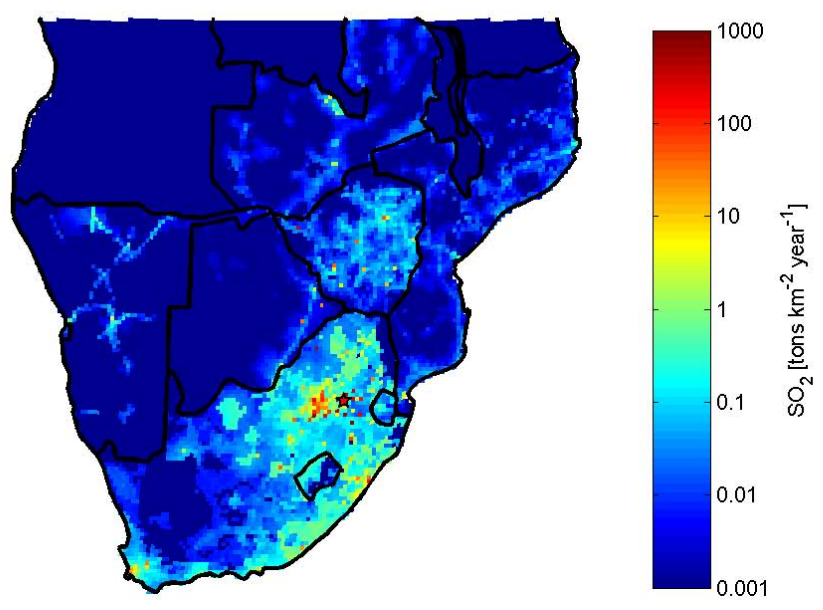

Fig. 3. Total $\mathrm{SO}_{2}$-emissions based on SAFARI2000 emission inventory (Fleming and van der Merwe, 2004). The measurement site is indicated with a red star.

and the mining industry contribute to high PM concentrations especially during the dry season.

\section{The measurement site}

The Elandsfontein measurement station $\left(26^{\circ} 14^{\prime} 43 \mathrm{~S}\right.$, $29^{\circ} 25^{\prime} 30 \mathrm{E}$ ) is located on the top of a hill approximately $200 \mathrm{~km}$ east of Johannesburg (Fig. 4) (e.g. Collett et al., 2010). The average altitude of the area varies between 1400 and $1600 \mathrm{~m}$ above mean sea level (a.m.s.l.), while 


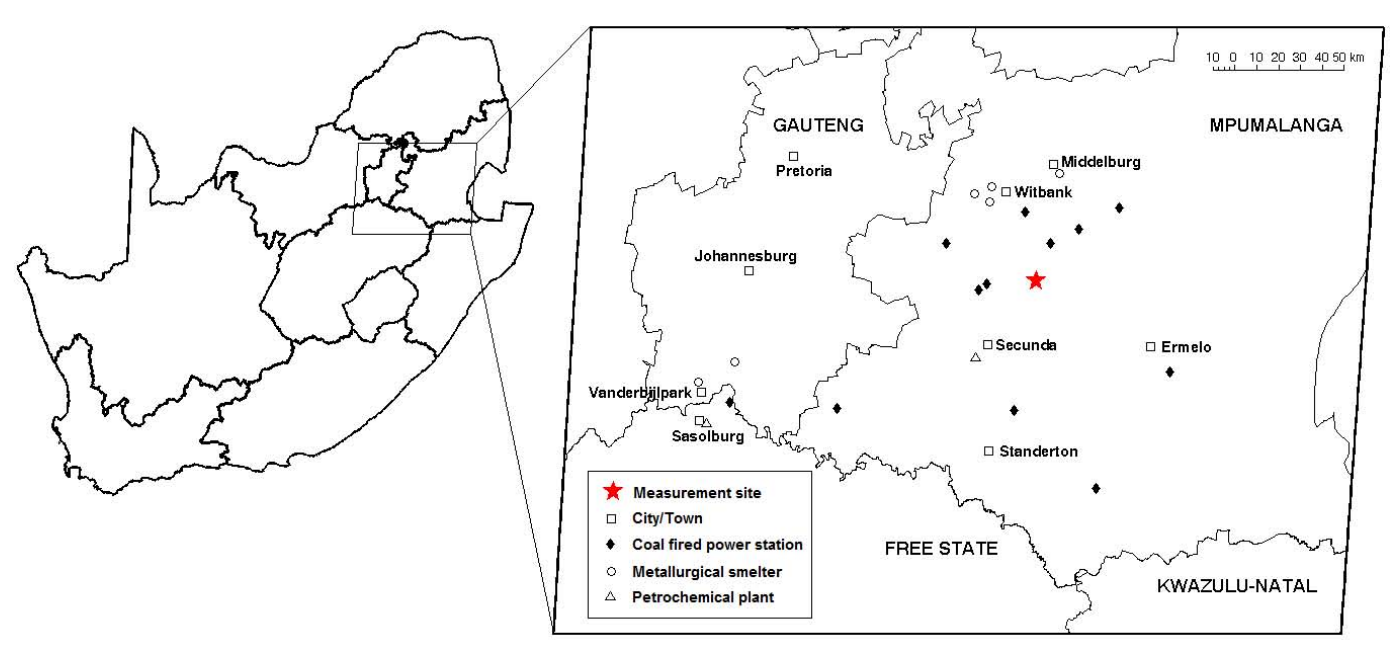

Fig. 4. Surroundings of the measurement site. The measurement site is indicated by a star and the major point sources by symbols described in legend.

the hill top where the measurement station was situated is $1750 \mathrm{~m}$ a.m.s.l. The shortest distance to the Indian Ocean is approximately $350 \mathrm{~km}$. The Drakensberg Mountains between the ocean and the site reach heights of 2000-3500 m a.m.s.l.

The major pollution sources within a $50 \mathrm{~km}$ radius include six coal-fired power plants to the west and north and a petrochemical coal plant to the south-west of the monitoring station (Fig. 4). The site is also relatively frequently impacted by metallurgical plants to the north. However, there are no major pollution sources within a radius of $20 \mathrm{~km}$ of the site (Lourens et al., 2011). In the sector between north-east and south-east only one major point source occurs.

The vegetation around the site is typical dry grassland pasture and farmland (Carruthers, 1997), with annual precipitation of about $700 \mathrm{~mm}$. The rain season is during the period October-March with very little rain during the winter (SAWS, 2009). The average maximum daytime temperatures in summer and winter are $26^{\circ} \mathrm{C}$ and $17^{\circ} \mathrm{C}$, respectively, and the corresponding average low night temperatures are $14^{\circ} \mathrm{C}$ and $1{ }^{\circ} \mathrm{C}$.

\section{Measurements and technical solutions}

The instrumentation at the Elandsfontein monitoring site was housed in two small, air conditioned huts. An additional metal shelter housed the pumps and compressor, whilst a LIDAR and Partisol aerosol sampler were in a separate shelter. In addition to the instrumentation, the site was equipped with tools and spare parts for routine maintenance and instrument servicing. The full aerosol measurements were started on 11 February 2009 and continued until 31 January 2011. During that period, measurements operated almost continuously, except for short time periods when maintenance, instrument service and power failures occurred.

A summary of the instruments utilised on site is shown in Table 1.

\subsection{Meteorological observations}

Basic meteorological parameters were measured on the site with a Vaisala WXT510 meteorological station (Vaisala, WTX510 specification sheet, 2010). The observations include wind direction and -speed with an acoustic anemometer, temperature, relative humidity and rain intensity. In addition to the weather station observations, solar radiation was measured with a PAR sensor and the potential temperature gradient with two Rotronic T-RH sensors stationed at heights of 2 and $8 \mathrm{~m}$.

\subsection{Trace gas observations}

The trace gases were measured as a part of ESKOM's routine air quality monitoring. $\mathrm{SO}_{2}, \mathrm{NO}_{\mathrm{x}}$ and $\mathrm{O}_{3}$ were measured with a Thermo Electron $43 \mathrm{C} \mathrm{SO}_{2}$ analyser, a Thermo Electron 42i $\mathrm{NO}_{\mathrm{x}}$ analyser and a Monitor Europe ML9810B $\mathrm{O}_{3}$ analyser respectively. $\mathrm{H}_{2} \mathrm{~S}$ was measured with a Thermo Electron $43 \mathrm{~A} \mathrm{SO}_{2}$ analyzer with a Thermo Electron 340 converter.

\subsection{Aerosol observations}

In order to avoid changes in aerosol properties due to humidity variations, all aerosol instruments were connected to an inlet drier (Tuch et al., 2009). The aerosol sample flow was kept below $35 \%$ relative humidity to avoid hygroscopic growth of particles, condensation and also electric sparkover inside the SMPS instrument. Particles larger than $10 \mu \mathrm{m}$ in aerodynamic diameter were excluded using a Rupprecht \& 
Table 1. Measured parameters and instrumentation.

\begin{tabular}{|c|c|c|c|}
\hline & Measured properties & Instrument & Period \\
\hline \multirow[t]{3}{*}{ Meteorology } & $T, p, \mathrm{RH}, \mathrm{WD}, \mathrm{WS}$ & Vaisala WXT510 & Oct 2008-Jan 2011 \\
\hline & Radiation & LiCor LI-190SB & Oct 2008-Jan 2011 \\
\hline & $\Delta T$ & Rotronic MP101A & Oct 2008-Jan 2011 \\
\hline \multirow[t]{4}{*}{ Trace gases } & $\mathrm{SO}_{2}$ & Thermo 43C & Continuous long-term \\
\hline & $\mathrm{NO}, \mathrm{NO}_{\mathrm{X}}$ & Thermo $42 \mathrm{i}$ & observations \\
\hline & & Monitor Europe ML9810B & \\
\hline & $\mathrm{H}_{2} \mathrm{~S}$ & Thermo model 340 and $43 \mathrm{~A}$ & \\
\hline \multirow{4}{*}{$\begin{array}{l}\text { Aerosol number size } \\
\text { distribution }\end{array}$} & $10-870 \mathrm{~nm}$ & SMPS & Feb 2009-Jan 2011 \\
\hline & $0.3-10 \mu \mathrm{m}$ & GRIMM 1.108 OPC & May-Aug 2009 \\
\hline & $0.3-2.2 \mu \mathrm{m}$ & GRIMM 7.309 OPC & Sep 2009-May 2010 \\
\hline & $0.75-10 \mu \mathrm{m}$ & Droplet Measurement & Sep 2009-Jan 2011 \\
\hline \multirow{4}{*}{ Aerosol absorption } & & & \\
\hline & Light absorption by & Thermo model 5012 MAAP & Feb 2009-Jan 2011 \\
\hline & $\mathrm{PM}_{10}$-aerosol & & \\
\hline & $\begin{array}{l}\text { Three wavelength light } \\
\text { absorption by } \mathrm{PM}_{10} \text {-aerosol }\end{array}$ & Radiance Research PSAP & Feb 2009-Jan 2011 \\
\hline Aerosol scattering & $\begin{array}{l}\text { Three wavelength light } \\
\text { scattering by } \mathrm{PM}_{10} \text {-aerosol }\end{array}$ & Ecotech Aurora 3000 & Feb 2009-Jan 2011 \\
\hline Aerosol Optical Depth & & Sunphotometer & Mar 2010-Jan 2011 \\
\hline $\begin{array}{l}\text { Aerosol chemical } \\
\text { composition }\end{array}$ & $\mathrm{PM}_{2.5}, \mathrm{PM}_{2.5-10}$ & Partisol & May 2009-Jan 2010 \\
\hline $\begin{array}{l}\text { Aerosol back } \\
\text { scattering }\end{array}$ & & PollyXT Raman lidar & Dec 2009-Jan 2011 \\
\hline
\end{tabular}

Patashnick $\mathrm{PM}_{10}$ inlet. Inside the measurement hut, the incoming air flow was split between the different instruments.

\subsubsection{Number size distributions}

A non-commercial Scanning Mobility Particle Sizer (SMPS) built by the Leibniz Institute for Tropospheric Research (IfT), Leipzig, Germany, was used. It consisted of a differential mobility particle sizer with a closed loop arrangement and a TSI 3010 condensation particle counter. The instrument measured particles between 10 and $870 \mathrm{~nm}$ diameter at a 5-min time resolution. The technical standards and data evaluation of our instrument complied with the recommendations given in Wiedensohler et al. (2011).

An optical particle counter (OPC, Grimm Model 1.108) was used in May through August 2009 for measuring the particle number size distribution in the diameter range $0.3-$ $20 \mu \mathrm{m}$. The flow rate of the OPC was 1.21 per minute (LPM). The particle number size distributions obtained from the OPC were combined with those measured with the SMPS to cover the diameter range of $10 \mathrm{~nm}$ to $10 \mu \mathrm{m}$ (the upper size limited by the $\mathrm{PM}_{10}$ inlet). The merging of the data was done by comparing the data on overlapping size range and scaling the OPC-concentrations to SMPS data.
In September 2009, the OPC was temporarily replaced with a Grimm model 7.309 OPC with a maximum particle diameter of $2.2 \mu \mathrm{m}$. In order to cover the missing range between $2.2 \mu \mathrm{m}$ and $10 \mu \mathrm{m}$, an additional OPC based on the optics of a DMT-CCNC counter with a measurement range of $0.7-10 \mu \mathrm{m}$ was installed.

\subsubsection{Aerosol light absorption measurements}

Light absorption by particles was measured with two different instruments: a Multi-Angle Absorption Photometer (MAAP) (Petzold and Schönlinner, 2004) at $\lambda=637 \mathrm{~nm}$ and a 3-wavelength Particle Soot Absorption Photometer (PSAP) (Virkkula et al., 2005; Virkkula, 2010) at $\lambda=467,530$, and $660 \mathrm{~nm}$. The PSAP sample was diluted by approximately 1:10 ratio. The performance of the dilution system and the wavelength dependence of absorption will not be discussed in the present paper. The MAAP reports Black Carbon (BC) concentrations but it actually measures light absorption and uses the mass absorption efficiency $6.6 \mathrm{~m}^{2} \mathrm{~g}^{-1}$ to calculate $\mathrm{BC}$ concentrations. We multiplied the $\mathrm{BC}$ concentrations by this efficiency to get the light absorption coefficient $\sigma_{\mathrm{AP}}$ at $\lambda=637 \mathrm{~nm}$. 


\subsubsection{Aerosol light scattering measurements}

The scattering of light by aerosol particles was measured with an Ecotech Aurora 3000 3-wavelength nephelometer. The original nephelometer light source was replaced with an opal glass light source (Logan, 2009) in the beginning of the measurement period and it measured at $\lambda=450 \mathrm{~nm}$, $525 \mathrm{~nm}$, and $635 \mathrm{~nm}$ (Müller et al., 2011). As the nephelometer was connected to a common inlet, it had to be modified to avoid counter flow in the instrument during calibration checks, which were scheduled to be conducted automatically every night. The internal blower for the sample flow was replaced with an external pump, a pneumatically driven ball valve was added in the inlet on top of the instrument and a three-way solenoid valve in the exhaust line connected to the pump. The internal sample blower power source was used to control the valves via a relay to keep the valves closed when the sample blower would be off, i.e. when reference zero or span air was sampled.

\subsubsection{Solar irradiance and aerosol optical depth measurements}

The solar irradiance and sky radiance was measured with a Cimel multichannel Sunphotometer. The Sunphotometer at Elandsfontein is part of the global AERONET observation network (http://aeronet.gsfc.nasa.gov/index.html) (Holben et al., 1998).

\subsubsection{Aerosol sampling and analysis of chemical composition}

In addition to the in situ measurements, aerosol particles were collected for chemical analysis at a flow rate of $1 \mathrm{~m}^{3} \mathrm{~h}^{-1}$ (at ambient conditions) on $47 \mathrm{~mm}$ quartz filters using a dichotomous aerosol sampler (2025 Partisol) equipped with a $\mathrm{PM}_{10}$ inlet. Quartz and paper filters were not pretreated prior to analysis. Fine particles (aerodynamic diameter below $2.5 \mu \mathrm{m}$ ) and coarse particles (aerodynamic diameter between 2.5 and $10 \mu \mathrm{m}$ ) were collected simultaneously every 6 days for a collection period of $24 \mathrm{~h}$ starting from 08:00 a.m. LT. To avoid negative sampling artefacts due to volatilization of ammonium nitrate from the quartz substrates, a Whatman 41 paper filter was sampled on the back of each quartz filter and the concentration of ammonium and nitrate were calculated as the sum of quartz and paper concentrations (Gilardoni et al., 2009, 2011).

Denuder units were employed to avoid positive sampling artefacts due to absorption of gas species on the sampling substrate. VOCs were removed upstream of the filters with an activated carbon honeycomb denuder, while nitric acid and ammonia were removed with glass denuders coated by sodium chloride and citric acid, respectively.

Concentrations of fine and coarse mass were determined by gravimetric analysis. Organic carbon (OC) and elemental carbon (EC) were measured by thermo-optical analysis with a Sunset Laboratory Dual-Optical analyzer (Birch and Cary, 1996). A modified version of the protocol EUSAAR-2 was employed (Cavalli et al., 2010) with a longer heating step to guarantee the complete evolution of carbonaceous aerosol fractions. Concentrations of the major inorganic ions $\left(\mathrm{Na}^{+}\right.$, $\mathrm{NH}_{4}^{+}, \mathrm{K}^{+}, \mathrm{Mg}^{2+}, \mathrm{Ca}^{2+}, \mathrm{Cl}^{-}, \mathrm{NO}_{3}^{-}, \mathrm{PO}_{4}^{3-}, \mathrm{SO}_{4}^{2-}$ ) were determined by ion chromatography (IC) after filter extraction with ultra pure water (Putaud et al., 2002).

Fine and coarse aerosol particles were collected on polycarbonate filters for a few weeks during September 2009 to identify dust chemical profile and quantify dust contribution to aerosol loading. All the chemical analyses were carried out by European Union Research centre JRC-Ispra.

\subsubsection{Vertical aerosol back scattering profiles}

A portable aerosol Raman LIDAR system extended PollyXT developed at the IfT, Germany (Althausen et al., 2009) was used. The system is a $3+2$ Raman LIDAR with a depolarization channel. The instrument was completely remotely controlled and all measurements were performed automatically. For aviation safety purposes, the system was equipped with an airplane detecting radar which shuts the laser beam down when an aircraft was detected. The Lidar was installed at the site in December 2009 and decommissioned in January 2011.

\subsection{Data logging systems}

Due to the fairly large number of instruments, the data logging system was based on a network of three PCs, as well as a separate PC for the Lidar. One of the three network PCs was used to run the SMPS system, another to control the sample dryer and to log data from the Nephelometer. All the other instruments except the LIDAR were connected to the third "Master" PC that used a 3G modem to send the measurement and diagnostics data to a server in Helsinki once a day. The data transmission from the LIDAR was operated via a separate $3 \mathrm{G}$ modem.

The data from the Nephelometer, MAAP, OPC and the weather station were collected via serial port connections. Analog signals for gases, temperature profile, solar radiation and instrument flow rates were collected with Pico ADC-16 (Pico Technology Ltd.) loggers.

\subsection{Power and signal protection}

Due to unreliable electricity supply, the occurrence of severe lightning and the location of the site on the top of a hill, the protection of the instruments was a major concern. The power and logging system were therefore equipped with a multi-step power protection system. First, the incoming power line was equipped with a ground breaker that reduced the incoming voltages in the event of a lightning surge on the incoming power line. Next, the incoming power was divided 
into three 3-phase groups. Each group had its own independent three-phase under- and over-voltage relay set at 210 and $240 \mathrm{~V}$, respectively. The relays had 1 to 3 -min time delays after a break to protect the instrumentation from repetitive short-lived irregularities in the power supply. The time delay of each user group was set differently to ramp up the electrical load more evenly after a power failure. Each group also has a residual current switch. For additional protection, the sensitive measurement instruments and computers were connected to an uninterrupted power supply (UPS) unit. The grounding of the measurement huts were connected to the grounding net of a $70 \mathrm{~m}$ high microwave link mast at the site. The mast provided additional protection for the entire measurement site.

In addition to protection against electrical disturbances, the measurement huts were equipped with temperature controllers to stop the measurements in case of high temperatures, e.g. malfunctioning air conditioner.

The signals from sensors outside the huts were optically isolated from the measurement computers. The serial port communication to the weather station, gas analysers, and solar radiation data loggers were isolated via optical fibre. These Pico-loggers were also protected with varistors against high voltages in the analogue signals.

\section{Site maintenance and data-analysis methods}

\subsection{Instrument maintenance and servicing}

The site was visited at least once every 12 days for calibrations, instrument servicing and routine maintenance. During the visits, all instruments and data logging were checked. A HEPA particle filter was placed on the common aerosol inlet, to verify that all the particle instruments showed zero concentrations. After this common inlet check, the zero of the SMPS was checked separately for leaks inside the instrument. The nephelometer automatic zero and span for the previous day was checked and if the values were out of range, full calibration and adjustment were performed. Due to potential variation of the $\mathrm{CO}_{2}$ span calibration, the span of the nephelometer was checked every two months with external high grade $\mathrm{CO}_{2}$. The flows of all inlets and sheath air were measured and recorded. If the flows were out of range, they were adjusted. The $\mathrm{PM}_{10}$-inlets were cleaned and greased with silicon grease. The filters of the Partisol sampler were changed and the status values recorded. The gas analyzers were calibrated once a month and adjusted when needed.

A full maintenance service of the site was carried out approximately every three months. This included more complicated service procedures such as the SMPS service, measurement instrumentation cell cleaning and other necessary servicing procedures.

In addition to on-site checks, the data downloaded to the server was visually inspected a few times per week for qual- ity assurance. If irregularities were found, extra site visits and necessary actions were carried out.

\subsection{Data corrections and calculations}

The measurement data from the site were visualized and corrected with a fit-for-purpose Matlab program set. First, all data were visually checked and obviously bad data rejected. Next, all data were corrected based on calibrations, zero and span, and flow checks. The changes between different checks were assumed to be linearly changing. All particle concentrations were corrected to STP conditions $\left(0^{\circ} \mathrm{C}\right.$ and $1013 \mathrm{hPa}$ ). The entire data set, except the SMPS data was then averaged for $15 \mathrm{~min}$ to provide a consistent and convenient set of data for further analysis.

For the optical observations the following procedures were applied. First, the scattering coefficients were corrected for pressure and temperature to ensure that the data discussed below were collected at 1013 mbar and $273 \mathrm{~K}$, which is the same as the absorption coefficients. The Ångström exponent of scattering, $\alpha_{\mathrm{SP}}$ was calculated for the whole wavelength range by taking logarithm of scattering coefficients and the respective wavelengths and fitting the data line to the line $\ln \left(\sigma_{\mathrm{SP}}, \lambda\right)=-\alpha_{\mathrm{SP}} \ln (\lambda)+C$, where $C$ is a constant that is irrelevant in this work. By using this $\alpha_{\text {SP }}$ the scattering coefficients were interpolated logarithmically to the MAAP wavelength $637 \mathrm{~nm}$ in order to calculate single-scattering albedo (SSA, $\left.\omega_{0}\right)$, i.e. the ratio of scattering to extinction coefficients: $\omega_{0}=\sigma_{\mathrm{SP}} /\left(\sigma_{\mathrm{SP}}+\sigma_{\mathrm{AP}}\right)$. The scattering and absorption coefficients and the single-scattering albedo discussed below are therefore all at $\lambda=637 \mathrm{~nm}$.

$\omega_{0}$ is a measure of the darkness of aerosols. At low values, the aerosol heats the atmosphere and at high values, it will cool it, depending also on other parameters, such as the aerosol upscatter fraction, aerosol optical depth and the albedo of the underlying surface (e.g. Haywood and Shine, 1995; Haywood and Boucher, 2000). For example, for a typical surface reflectance of grass of 0.2 (e.g. Betts and Ball, 1997) an aerosol may heat the atmosphere if $\omega_{0}$ is less than $\sim 0.75$ and cool it if it is larger than that. For brighter surfaces, such as snow, albedo is $>0.9$ and the limiting $\omega_{0}$ is higher. $\omega_{0}$ is approximately 0.3 for pure black carbon, i.e. light absorbing carbon particles (e.g. Mikhailov et al., 2006) so it would heat the atmosphere above both grass and snow and 1 for purely scattering aerosol, for example ammonium sulphate, so it cools the atmosphere above both surfaces.

The $\alpha_{\mathrm{SP}}$ is not just used in the interpolation above. It is often used as a qualitative indicator of the particle size distribution (Ångström, 1929). Large values $\left(\alpha_{\mathrm{SP}}>2\right)$ are associated with anthropogenic aerosols and small values are related to a strong contribution of sea salt or mineral dust particles (e.g. Delene and Ogren, 2002). This dependence is not definite, as discussed, e.g. by Schuster et al. (2006), Garland et al. (2008), and Virkkula et al. (2011). 


\section{Results}

Due to the large number of observations, the focus of this paper, in addition to the site description, is on trace gas time series and basic aerosol properties. Aspects of Lidar observations, new particle formation, aerosol chemical composition and detailed optical properties will be published separately. A summary of all results is presented in Table 2 and discussed in more detail below. The polluted days in Table 2 and Figs. 9 and 11 were defined based on time the air masses spent over the most polluted areas of the Highveld and include $10 \%$ of the trajectories crossing most grid points in these areas.

\subsection{Meteorological data}

Figure 5 represents the monthly statistics for (a) temperature, (b) relative humidity, (c) wind speed and (d) monthly accumulated precipitation. The strong seasonal cycles of temperate, humidity and precipitation are clearly visible. During the winter, typical daily temperatures were below $10^{\circ} \mathrm{C}$ and relative humidity was around $50 \%$. The relatively high $\mathrm{RH}$ values are related to the position of the station at the top of the hill. The summer temperatures typically did not reach values above $25^{\circ} \mathrm{C}$ due to the location - much higher values were observed at lower altitudes in the surrounding area. In general the highest wind speeds were observed during spring. The most important annual cycle is, however, precipitation with very limited, if any, rain during the winter. This leads to widespread wild and man-made grassland fires throughout the area during winter. In contrast, the rainy season prevents the fires during summer and reduces windblown dust emissions.

\subsection{Trace gases}

Ozone concentrations varied mostly between 5 to $80 \mathrm{ppb}$ (Fig. 6a). The monthly 50\% percentile values indicated in Fig. 6 were of the same magnitude as average monthly values reported by Lourens et al. (2011) for several monitoring stations in the Highveld area. Seasonal variations of $\mathrm{O}_{3}$ were observed, with the highest concentration periods corresponding to the dry winters (June-August) or early spring prior to the onset of rains (September-October). Somewhat similar behaviour was also observed by Venter et al. (2012) at Marikana in the western Bushveld Igneous Complex $\sim 100 \mathrm{~km}$ west of the Johannesburg Metropolitan area. In that area, concentrations were somewhat lower than at Elandsfontein, probably due to stronger local $\mathrm{NO}_{\mathrm{x}}$ sources from domestic burning. The generally high ozone levels measured at the EUCAARI site can most likely be attributed to the abundance of sunshine and the presence of the $\mathrm{O}_{3}$ precursor species i.e. $\mathrm{NO}_{2}$ and VOCs in relatively high concentrations (Lourens et al., 2011; Collett et al., 2010; Sillman, 1999; Zunckel et al., 2005), due to the very well documented industrial activities mentioned earlier. Additionally, $\mathrm{CO}$ (another known $\mathrm{O}_{3}$ precursor) concentrations are expected to increase due to wild fire activities during the dry season, explaining the seasonal $\mathrm{O}_{3}$ behaviour observed. It can be expected that higher tropospheric $\mathrm{O}_{3}$ will occur further away from this source region, as the $\mathrm{O}_{3}$-precursors have more time to be converted to $\mathrm{O}_{3}$ during the transportation. Martins et al. (2007) and Josipovic et al. (2010) reported much higher $\mathrm{O}_{3}$ levels at background sites further away from the Highveld. The current South African ambient air quality standard for ozone is $61 \mathrm{ppb}$ for an 8-h moving average, which is calculated from the 1-h moving averages (NEMA: AQA, 39 of 2004, 2009). From the data presented in Fig. 6, it is clear that regular exceedances of this standard occurred during the measurement period. Both the studies mentioned earlier (Martins et al., 2007; Josipovic et al., 2010) utilized passive sampling and could therefore not comment on exceedances of the 8-h moving average standard. However, considering that $\mathrm{O}_{3}$ levels regularly exceeded this standard at the EUCAARI measurement site and that it is likely to be much higher as the plume from this source region is transported, it is evident that similar to e.g. central US (Parrish et al., 2011) the interior of South Africa has an existing $\mathrm{O}_{3}$ problem. A spatial investigation of $\mathrm{O}_{3}$ pollution levels over the interior of South Africa, utilizing active samplers, is required to quantify this issue further. Considering that South Africa is a semi-arid country, crop damage by $\mathrm{O}_{3}$ (Zunkel et al., 2005) could in future compound climatic effects.

Both $\mathrm{NO}_{\mathrm{x}}$ and $\mathrm{SO}_{2}$ (Fig. 6b, c) indicated seasonal variations, with peak periods in the winter months (June-August). $\mathrm{NO}_{\mathrm{x}}$ concentrations also peaked in December 2009, which was the exception to the rule. The winter peaks can be attributed to trapping of pollutants by several well defined inversion layers dominating in winter, recirculation patterns preventing further dispersion (Garstang et al., 1996 Tyson et al., 1996; Tyson and Preston-Whyte, 2000) and reduced wet removal due to a lack of precipitation. $\mathrm{NO}_{\mathrm{x}}$ in winter may also have been augmented by biomass burning emissions in the region and household combustion, since fuels consumed in these activities have relatively high nitrogen contents (Collett et al., 2010). As expected, $\mathrm{NO}_{2}$ and $\mathrm{SO}_{2}$ regularly exceeded South African ambient air quality standards (NEMA: AQA, 39 of 2004, 2009), especially if the site was directly impacted by a plume from one of the large point sources in the area. As mentioned previously, the Highveld of South Africa is a $\mathrm{NO}_{2}$ hotspot, with satellite retrievals indicating that the Tropospheric $\mathrm{NO}_{2}$ column density of this area is comparable to that observed for central and northern Europe, eastern North-America and south-east Asia (Beirle et al., 2006; Toenges-Schuller et al., 2006; Lourens et al., 2012). $\mathrm{SO}_{2}$ in this area is emitted with $\mathrm{NO}_{\mathrm{x}}$ from large point sources (Lourens et al., 2011; Collett et al., 2010). The relatively high levels of $\mathrm{NO}_{2}$ and $\mathrm{SO}_{2}$ in this area lead to the proclamation of this area in 2007 (in terms of the South African National Environmental Management: Air Quality 

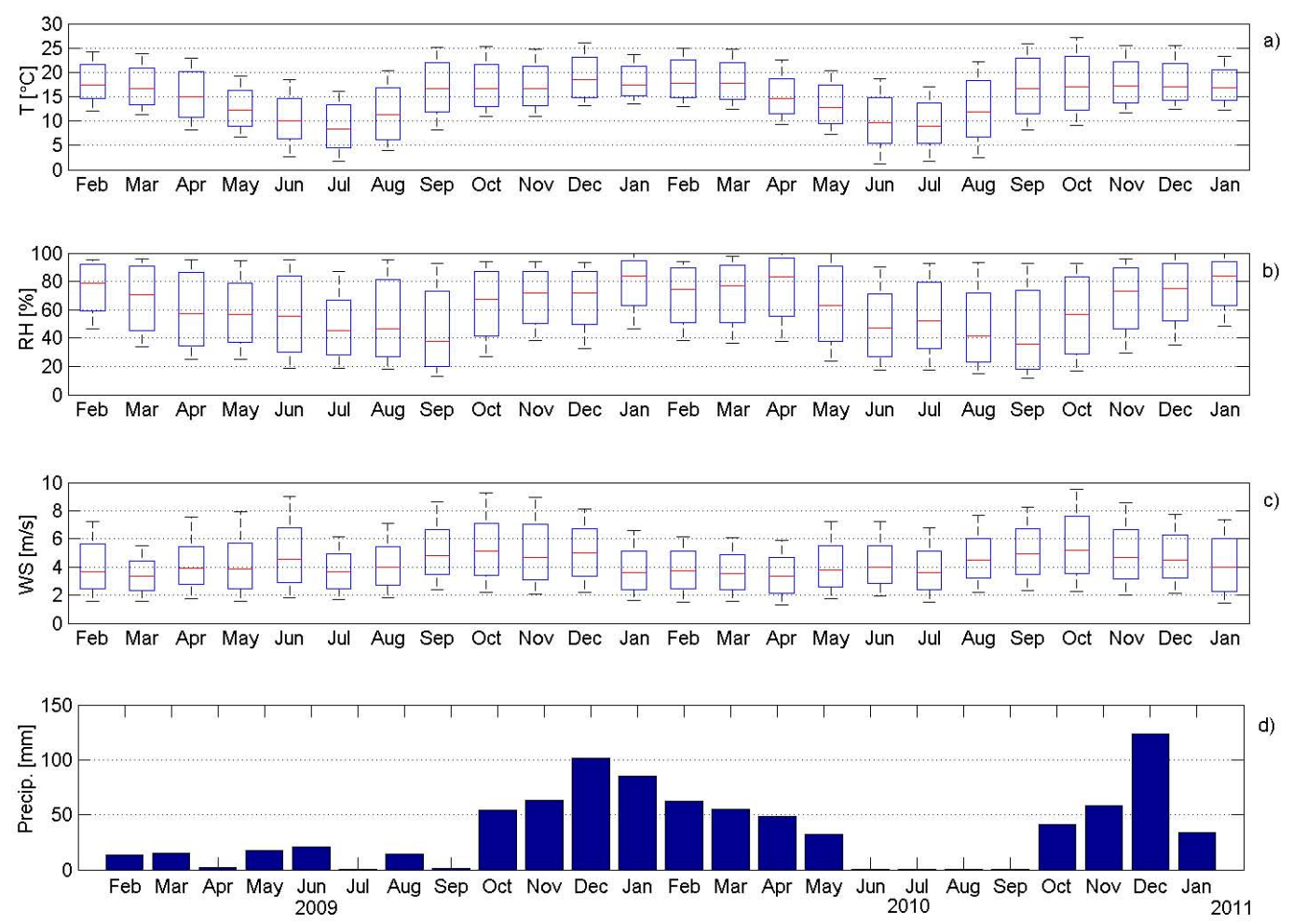

Fig. 5. Meteorological characteristics of the Elandsfontein observation site on the South African Highveld: (a) temperature, (b) relative humidity, (c) wind speed, and (d) monthly accumulated precipitation for the period 11 February 2009-31 January 2011. The red lines represent the $50 \%$ percentile, the blue boxes the 25 and $75 \%$ percentiles and the black whiskers the 5 and $95 \%$ percentiles, except in (d).

Act 39 of 2004) as a national air pollution hotspot termed the Highveld Priority Area (Notice of intention, 2007).

$\mathrm{H}_{2} \mathrm{~S}$ (Fig. 6d) concentrations were generally lower than that of $\mathrm{SO}_{2}$. This can be attributed to the fact that most of the large point sources in the area, i.e. the array of coalfired power stations, utilise oxidative combustion processes, favouring the formation of $\mathrm{SO}_{2}$ rather than $\mathrm{H}_{2} \mathrm{~S}$. Possible $\mathrm{H}_{2} \mathrm{~S}$ sources in this region include biogenic activities, large scale cattle farming which is usually conducted in parallel with maize (corn) production and possibly a contribution from the petrochemical industry in this area. In this process, coal is transformed into liquid fuels, which requires less oxidative combustion conditions. Seasonal variations of $\mathrm{H}_{2} \mathrm{~S}$, with peaks in the dry winters and early spring before the onset of rains is similar to the $\mathrm{NO}_{\mathrm{x}}$ and $\mathrm{SO}_{2}$ seasonal trends and can be attributed to trapping of pollution by strong inversion layers, recirculation (Garstang et al., 1996; Tyson et al., 1996; Tyson and Preston-Whyte, 2000) and the lack of wet removal via precipitation.

In general, levels of the $\mathrm{SO}_{2}, \mathrm{NO}_{\mathrm{x}}$ and $\mathrm{O}_{3}$ were relatively high, if compared to measurements conducted globally (e.g. Carmichael, 2003; Beirle et al., 2006), but below the concentrations of highly polluted parts of Asia.

\subsection{Aerosol number, volume and optical properties}

The seasonal behaviour of aerosol volume and number are shown in Fig. 7. $\mathrm{PV}_{10}$ and $\mathrm{PV}_{2.5}$ were significantly higher during the second spring period. One possible explanation is the drier winter that occurred in 2010 with no rain, compared to the 2009 winter when some, even limited rain showers potentially limited dust emissions. As a similar trend is not visible in aerosol absorption (Fig. 8c), it is assumed that the phenomena was not related to regional burning. However, in general the windy spring periods, as well as the regionally polluted dry winter seasons, exhibited increased coarse particle volumes. The particle number follows a similar pattern as $\mathrm{PV}_{10}$. Basically one could assume particle number to be positively related to $\mathrm{SO}_{2}$ concentration and inverse to preexisting particle surface. However, as this is not the case, it is assumed that this strange behaviour have to be related to variability of seasonal meteorology.

The aerosol optical properties shown in Fig. 8 have a clear seasonal cycle, and this applies both to the extensive properties scattering coefficient $\left(\sigma_{\mathrm{SP}}\right)$ and absorption coefficient $\left(\sigma_{\mathrm{AP}}\right)$, as well as the intensive properties Ångström exponent of scattering $\left(\alpha_{\mathrm{SP}}\right)$ and single-scattering albedo $\left(\omega_{0}\right)$. The largest scattering and absorption coefficients were observed in the winter and spring months (June-October) and the 
Table 2. Statistical summary of 15-min averaged data during the whole period, periods when trajectories crosses over multiple emission grid points, in spring (September-November), summer (December-February), autumn (March-May), and winter (June-August). Values are means.

\begin{tabular}{|c|c|c|c|c|c|c|c|}
\hline Parameter & Unit & $\begin{array}{l}\text { Whole } \\
\text { period }\end{array}$ & Polluted & $\begin{array}{l}\text { Spring } \\
\text { (Sep-Nov) }\end{array}$ & $\begin{array}{l}\text { Summer } \\
\text { (Dec-Feb) }\end{array}$ & $\begin{array}{l}\text { Autumn } \\
\text { (Mar-May) }\end{array}$ & $\begin{array}{l}\text { Winter } \\
\text { (Jun-Aug) }\end{array}$ \\
\hline $\begin{array}{l}\text { Temperature } \\
\text { (std) }\end{array}$ & {$\left[{ }^{\circ} \mathrm{C}\right]$} & $\begin{array}{l}15.2 \\
(5.5)\end{array}$ & $\begin{array}{l}16.5 \\
(5.3)\end{array}$ & $\begin{array}{l}16.9 \\
(5.5)\end{array}$ & $\begin{array}{l}18.4 \\
(4.1)\end{array}$ & $\begin{array}{l}17.6 \\
(3.9)\end{array}$ & $\begin{array}{l}10.2 \\
(4.8)\end{array}$ \\
\hline $\begin{array}{l}\text { RH } \\
\text { (std) }\end{array}$ & {$[\%]$} & $\begin{array}{l}62.0 \\
(24.9)\end{array}$ & $\begin{array}{l}57.9 \\
(23.0)\end{array}$ & $\begin{array}{l}44.7 \\
(27.4)\end{array}$ & $\begin{array}{l}70.6 \\
(19.4)\end{array}$ & $\begin{array}{l}70.6 \\
(20.4)\end{array}$ & $\begin{array}{l}53.2 \\
(24.6)\end{array}$ \\
\hline $\begin{array}{l}\mathrm{O}_{3} \\
\text { (std) }\end{array}$ & [ppb] & $\begin{array}{l}37.1 \\
(17.3)\end{array}$ & $\begin{array}{l}41.3 \\
(18.5)\end{array}$ & $\begin{array}{l}41.3 \\
(17.6)\end{array}$ & $\begin{array}{l}36.2 \\
(13.9)\end{array}$ & $\begin{array}{l}30.8 \\
(17.2)\end{array}$ & $\begin{array}{l}45.1 \\
(18.6)\end{array}$ \\
\hline $\begin{array}{l}\mathrm{SO}_{2} \\
\text { (std) }\end{array}$ & [ppb] & $\begin{array}{l}11.5 \\
(13.9)\end{array}$ & $\begin{array}{l}14.0 \\
(15.8)\end{array}$ & $\begin{array}{l}14.7 \\
(15.8)\end{array}$ & $\begin{array}{l}13.1 \\
(14.7)\end{array}$ & $\begin{array}{l}8.9 \\
(8.2)\end{array}$ & $\begin{array}{l}12.6 \\
(16.4)\end{array}$ \\
\hline $\begin{array}{l}\mathrm{NO}_{\mathrm{x}} \\
\text { (std) }\end{array}$ & [ppb] & $\begin{array}{l}15.1 \\
(18.7)\end{array}$ & $\begin{array}{l}18.6 \\
(21.1)\end{array}$ & $\begin{array}{l}11.9 \\
(14.3)\end{array}$ & $\begin{array}{l}13.8 \\
(17.4)\end{array}$ & $\begin{array}{l}17.9 \\
(17.1)\end{array}$ & $\begin{array}{l}23.7 \\
(25.4)\end{array}$ \\
\hline $\begin{array}{l}\mathrm{H}_{2} \mathrm{~S} \\
\text { (std) }\end{array}$ & [ppb] & $\begin{array}{l}3.2 \\
(4.6)\end{array}$ & $\begin{array}{l}5.6 \\
(4.0)\end{array}$ & $\begin{array}{l}3.7 \\
(4.7)\end{array}$ & $\begin{array}{l}3.0 \\
(4.2)\end{array}$ & $\begin{array}{l}2.3 \\
(3.1)\end{array}$ & $\begin{array}{l}5.2 \\
(7.4)\end{array}$ \\
\hline $\begin{array}{l}N_{\text {tot }} \\
\text { (std) }\end{array}$ & {$\left[\mathrm{cm}^{-3}\right]$} & $\begin{array}{l}6310 \\
(8700)\end{array}$ & $\begin{array}{l}7000 \\
(7490)\end{array}$ & $\begin{array}{l}10050 \\
(12460)\end{array}$ & $\begin{array}{l}6260 \\
(8040)\end{array}$ & $\begin{array}{l}4780 \\
(6800)\end{array}$ & $\begin{array}{l}6890 \\
(7230)\end{array}$ \\
\hline $\begin{array}{l}\mathrm{PV}_{10} \\
(\mathrm{std})\end{array}$ & {$\left[\mu \mathrm{m}^{3} \mathrm{~m}^{-3}\right]$} & $\begin{array}{l}9.3 \\
(10.8)\end{array}$ & $\begin{array}{l}12.3 \\
(12.6)\end{array}$ & $\begin{array}{l}22.8 \\
(17.5)\end{array}$ & $\begin{array}{l}4.7 \\
(7.0)\end{array}$ & $\begin{array}{l}8.1 \\
(9.0)\end{array}$ & $\begin{array}{l}12.6 \\
(11.9)\end{array}$ \\
\hline $\begin{array}{l}\sigma_{\mathrm{AP}} \\
(\mathrm{std})\end{array}$ & {$\left[\mathrm{Mm}^{-1}\right]$} & $\begin{array}{l}8.3 \\
(9.2)\end{array}$ & $\begin{array}{l}10.4 \\
(10.4)\end{array}$ & $\begin{array}{l}16.5 \\
(11.8)\end{array}$ & $\begin{array}{l}2.9 \\
(3.2)\end{array}$ & $\begin{array}{l}4.8 \\
(4.6)\end{array}$ & $\begin{array}{l}12.7 \\
(13.0)\end{array}$ \\
\hline $\begin{array}{l}\sigma_{\mathrm{SP}} \\
(\mathrm{std})\end{array}$ & {$\left[\mathrm{Mm}^{-1}\right]$} & $\begin{array}{l}49.5 \\
(55.2)\end{array}$ & $\begin{array}{l}66.4 \\
(55.8)\end{array}$ & $\begin{array}{l}80.6 \\
(60.6)\end{array}$ & $\begin{array}{l}23.0 \\
(22.7)\end{array}$ & $\begin{array}{l}39.7 \\
(38.9)\end{array}$ & $\begin{array}{l}63.4 \\
(61.9)\end{array}$ \\
\hline $\begin{array}{l}\omega_{0} \\
(\mathrm{std})\end{array}$ & & $\begin{array}{l}0.84 \\
(0.08)\end{array}$ & $\begin{array}{l}0.86 \\
(0.06)\end{array}$ & $\begin{array}{l}0.83 \\
(0.05)\end{array}$ & $\begin{array}{l}0.88 \\
(0.07)\end{array}$ & $\begin{array}{l}0.88 \\
(0.07)\end{array}$ & $\begin{array}{l}0.80 \\
(0.10)\end{array}$ \\
\hline $\begin{array}{l}\alpha_{\mathrm{SP}} \\
(\mathrm{std})\end{array}$ & & $\begin{array}{l}1.5 \\
(0.4)\end{array}$ & $\begin{array}{l}1.6 \\
(0.3)\end{array}$ & $\begin{array}{l}1.4 \\
(0.3)\end{array}$ & $\begin{array}{l}1.7 \\
(0.3)\end{array}$ & $\begin{array}{l}1.6 \\
(0.4)\end{array}$ & $\begin{array}{l}1.5 \\
(0.4)\end{array}$ \\
\hline
\end{tabular}

lowest in summer and autumn (December-March) (Fig. 8b, c). The seasonality of both the emissions and the meteorological conditions are likely the cause. In winter the industrial activities (e.g. higher electricity consumption) and domestic space heating are at their most active state. There are also large emissions due to wildfires in these months. Additionally in winter the mixing height of the boundary layer is lower and the atmospheric residence times due to atmospheric re-circulation and limited wet deposition (Fig. 5d) are longer, leading to an accumulation of the aerosol particles. In summer, mixing height is higher, which leads to lower pollutant concentrations due to more dilution. Other reasons for lower concentrations are frequent below- and incloud scavenging, and less persistent weather types leading to advection of pollutants out of the Highveld area.

If the seasonal cycle of $\sigma_{\mathrm{SP}}$ and $\sigma_{\mathrm{AP}}$ were due to that of dilution mechanisms, for instance the seasonal variation of the mixing height only, there would be no seasonal cycle of $\omega_{0}$ (Fig. 8d). However, there is a clear seasonal cycle of $\omega_{0}$ so that the darkest aerosols with monthly medians of approximately 0.8 during the dry conditions were observed in winter (Fig. 8d). The average standard deviation was $0.8 \pm 0.1$ (Table 2). In summer, monthly median $\omega_{0}$ was closer to 0.9 and above (Fig. 8d), and the average was $0.88 \pm 0.07$. This seasonal cycle is likely due to differences in the sources and seasonal source strengths of scattering and absorbing particles. This includes not only anthropogenic emissions: in summer the emissions of various biogenic organic compounds are higher than in winter. This combined with more sunlight would lead to a larger contribution of secondary organic aerosols (SOA) in summer than in winter. The seasonal cycle of $\omega_{0}$ at Elandsfontein resembles that observed at some very different environments: an Arctic background site in Barrow, Alaska (Delene and Ogren, 2002) a boreal forest site 

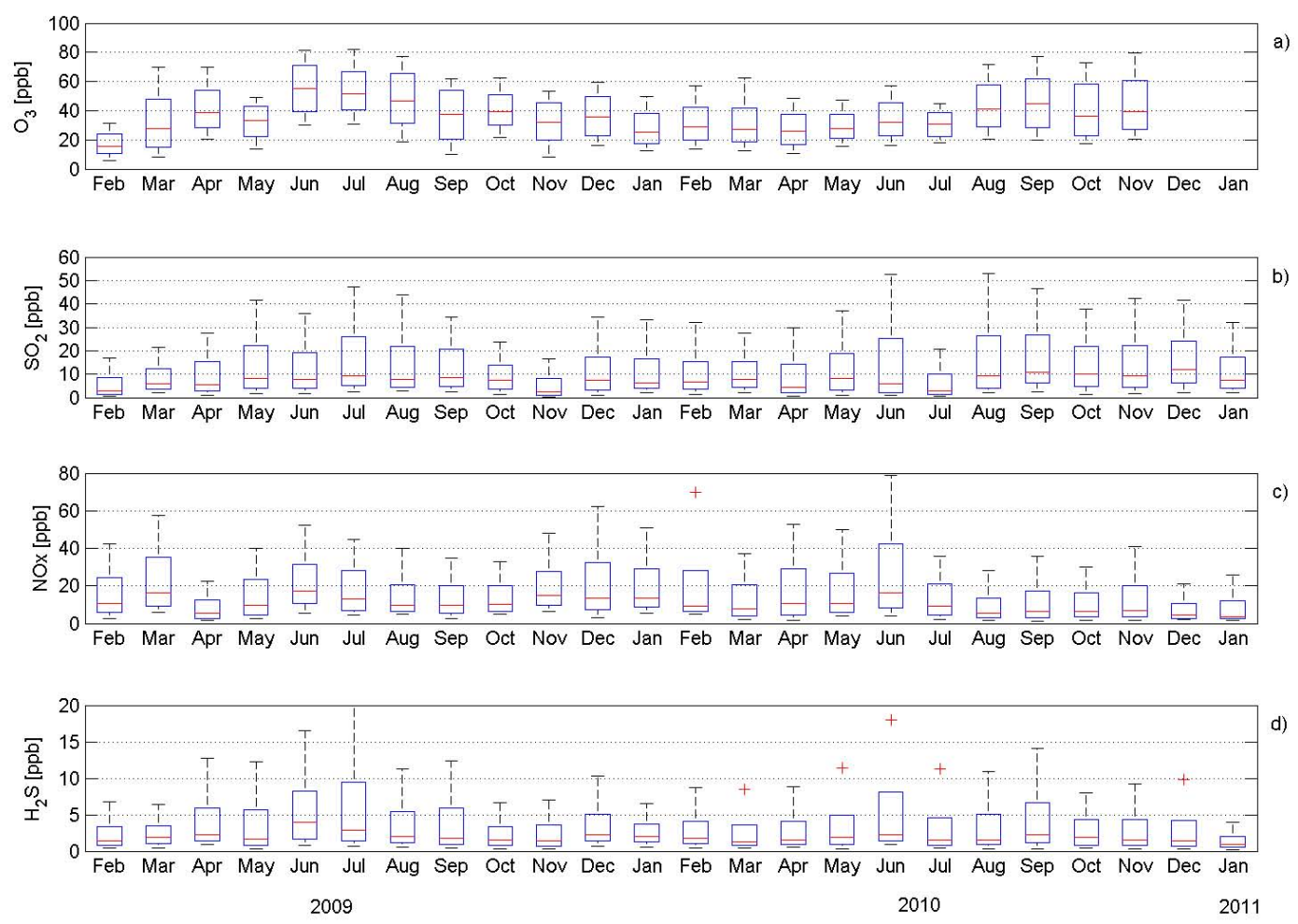

Fig. 6. Concentrations of gas phase species at Elandsfontein: monthly averages of (a) $\mathrm{O}_{3}$, (b) $\mathrm{SO}_{2}$, (c) $\mathrm{NO}_{\mathrm{x}}$, and (d) $\mathrm{H}_{2} \mathrm{~S}$ on the basis of hourly data for the period 11 February 2009-31 January 2011. The red lines represent the $50 \%$ percentile, the blue boxes the 25 and $75 \%$ percentiles and the black whiskers the 5 and $95 \%$ percentiles.

in Finland (Virkkula et al., 2011) and several stations, even though not all, in the free troposphere of the Northern Hemisphere (Andrews et al., 2011). On the other hand, at two North American continental sites in Illinois and Oklahoma the seasonal cycle of $\omega_{0}$ was different, with the summer medians lower than in winter (Delene and Ogren, 2002).

The seasonal cycle of the Ångström exponent (Fig. 8a) is the weakest of the cycles shown in Fig. 8. The monthly medians vary from about 1.5 to 1.7 , mainly above the overall average 1.5. These values are somewhat lower than those reported from North American continental sites in Illinois and Oklahoma, where $\alpha_{\mathrm{SP}}$ for $\mathrm{PM}_{10}$ particles was 2.03 and 1.94 but higher than at a site dominated by marine aerosols in Sable Island, Nova Scotia, where the average was 0.77 (Delene and Ogren, 2002). Elandsfontein is relatively far from the oceans so the amount of sea salt particles is negligible. The lowest values, $\alpha_{\mathrm{SP}}<1$ observed almost each month may therefore be an indication of soil dust particles. However, a more detailed analysis of the relationships between $\alpha_{\mathrm{SP}}$ and size distributions is out of the scope of this paper.

Aerosol optical properties are also compared with independent measurements with a simple approach. The light scattering coefficient is known to be highly correlated with aerosol mass concentration (e.g. Charlson et al., 1967) and values of mass scattering efficiency have been published for several sites (e.g. Hand and Malm, 2007; Malm and Hand
2007). The total aerosol volume concentration was therefore calculated from the size distributions and multiplied with the density $\left(1.7 \mathrm{~g} \mathrm{~cm}^{-3}\right.$ was used) to get an estimate of the aerosol mass concentration in the size range $D_{\mathrm{p}}<10 \mu \mathrm{m}$, i.e. $\mathrm{PM}_{10}$. It is also of interest to know how large a fraction of aerosol mass is due to light absorbing carbon, or $\mathrm{BC}$ as the MAAP reports the concentration. The $\mathrm{BC}$ concentrations were compared with the $\mathrm{PM}_{10}$ concentrations obtained from the volume concentrations. The comparison was done both by using all the data and separating only data that were associated with trajectories that passed over the industrial pollution sources as discussed earlier.

The linear regression of $\sigma_{\mathrm{SP}} \mathrm{vs}$. $\mathrm{PM}_{10}$ for all data yields the mass scattering efficiency of $2.3 \pm 1.8 \mathrm{~m}^{2} \mathrm{~g}^{-1}$, at $\lambda=637 \mathrm{~nm}$ (Fig. 9a). The uncertainty is the standard deviation of the slope obtained from a linear fit. This value is in line with those obtained from other sites. Hand and Malm (2007) reviewed the published aerosol mass scattering efficiencies from numerous ground-based measurements since 1990. The average total (fine + coarse) specific mass scattering efficiency for mixed aerosol was $2.2 \pm 1.0 \mathrm{~m}^{2} \mathrm{~g}^{-1}$ (Hand and Malm, 2007).

The linear regression of $\mathrm{BC}$ vs. $\mathrm{PM}_{10}$ concentrations suggests that in general $6.5 \pm 4.1 \%$ of $\mathrm{PM}_{10}$ is BC (Fig. 9b). The data are spread at a large range around this regression line, however. There were periods when $\mathrm{BC}$ dominated the 

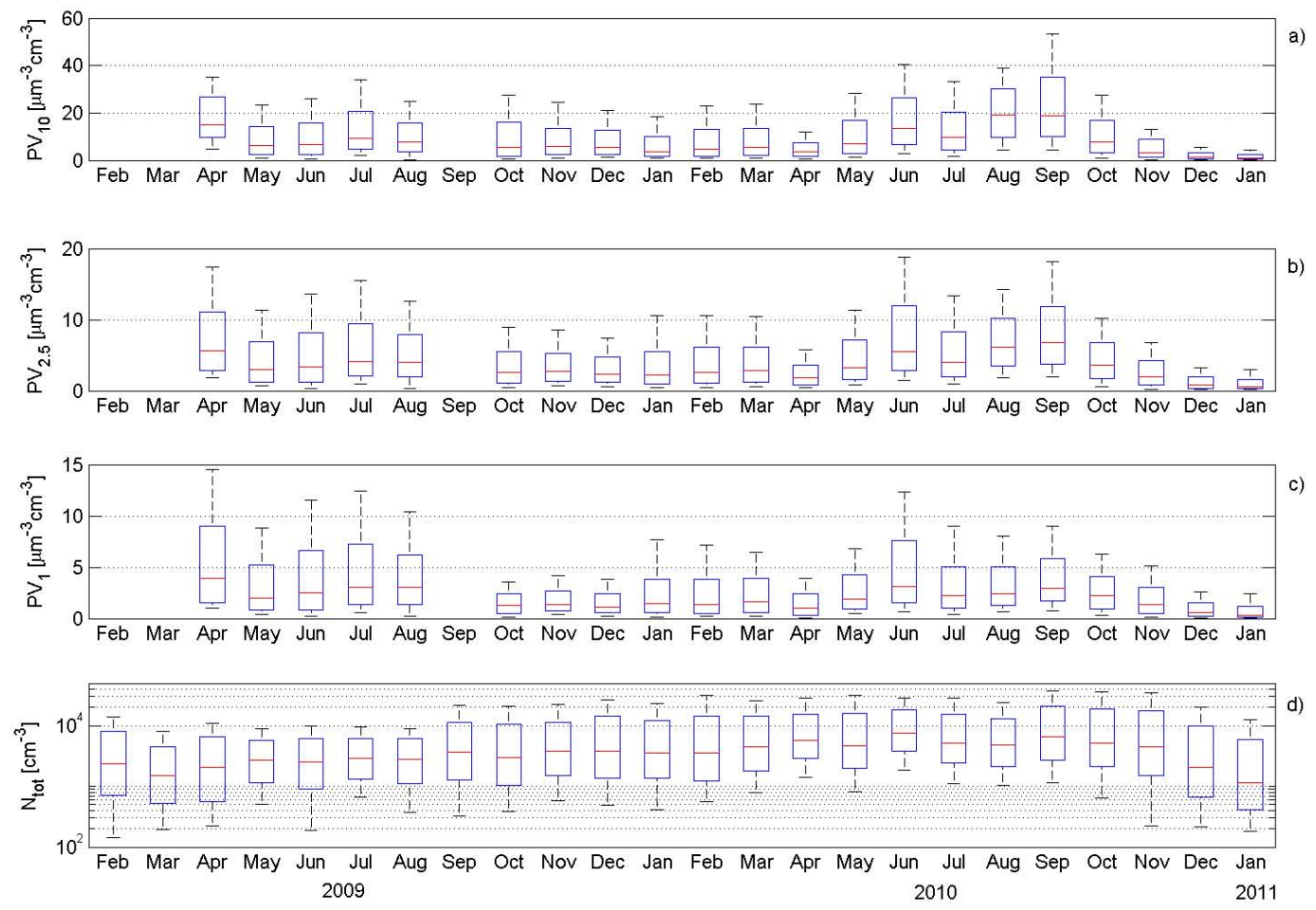

Fig. 7. Aerosol volume and number at Elandsfontein: (a) volume of $<10 \mu \mathrm{m}$ particles, (b) volume of $<2.5 \mu \mathrm{m}$ particles, (c) volume of $<1 \mu \mathrm{m}$ particles, and (d) total number of $<10 \mu \mathrm{m}$ particles for the period 11 February 2009-31 January 2011. The red lines represent the $50 \%$ percentile, the blue boxes the 25 and $75 \%$ percentiles and the black whiskers the 5 and $95 \%$ percentiles.

aerosol mass: in $0.9 \%$ of the 15 min data more than $50 \%$ of $\mathrm{PM}_{10}$ was $\mathrm{BC}$; these data points also have the lowest singlescattering albedo. It has to be emphasized, however, that the duration of these periods with high $\mathrm{BC}$ mass fraction was always short, on the average $45 \mathrm{~min}$, the longest was $5 \mathrm{~h}$, and during these times mass concentration was low. As previously indicated, filter samples were also taken for OC/EC analyses; however, the results will be presented in a forthcoming paper. These samples were taken for $24 \mathrm{~h}$ so there the sample total mass will be dominated by the period when $\mathrm{BC}$ mass fraction was clearly lower than $50 \%$ and the resulting EC mass fraction will consequently also be much lower than $50 \%$.

In the scatter plots of $\sigma_{\mathrm{SP}}$ vs. $\mathrm{PM}_{10}$ and $\mathrm{BC}$ vs. $\mathrm{PM}_{10}$ the data classified as "polluted" did not differ substantially from the rest: the ranges of all data are more or less the same, high concentrations of scattering and absorbing aerosol are observed in both classes. This may suggest that there are uncertainties in the back trajectories, in the emission inventories, or in the contribution of local biomass burning on pollutant levels. It may also indicate that in the upper plateau air masses are so well mixed with aged pollution that the effect of single sources cannot be observed easily. The only clear difference can be observed when $\omega_{0}$ and $\alpha_{\mathrm{SP}}$ are compared with the aerosol volume concentration (Fig. 9c, d).
The most absorbing aerosol events, i.e. those data points with $\omega_{0}<0.6$ were practically all associated with those back trajectories that did not pass over the known emission sources (Fig. 9c). On the other hand, these data points were associated with fairly low aerosol volume concentrations, $\mathrm{PV}_{10}<$ $1 \mu \mathrm{m}^{3} \mathrm{~cm}^{-3}$. Aerosol chemical characterization at the study site showed that light absorption of $\mathrm{BC}$ particles in relatively clean air masses was enhanced by coating effect; this would increase the contribution of absorption to aerosol extinction, increasing the single scattering albedo (Gilardoni et al., 2011). Another explanation could be that some smallscale combustion sources were located in the vicinity of the station so that particle volume did not have time to grow by formation of secondary scattering material (i.e. sulphate). Unfortunately, due to the short duration of these highly absorbing aerosol events, no aerosol chemical composition data are available to discriminate between the two hypotheses.

The Ångström exponent of scattering, $\alpha_{\mathrm{SP}}$ had a very weak correlation with aerosol volume concentration (Fig. 9d). However, of note was that the largest values were observed when the volume concentrations were low. On the other hand, these were the darkest aerosols. The qualitative relationship between $\alpha_{\mathrm{SP}}$ and particle size is that large $\alpha_{\mathrm{SP}}$ values are associated with small particles. This further supports the interpretation that the most absorbing aerosols are some small particles that have not had time to grow. 

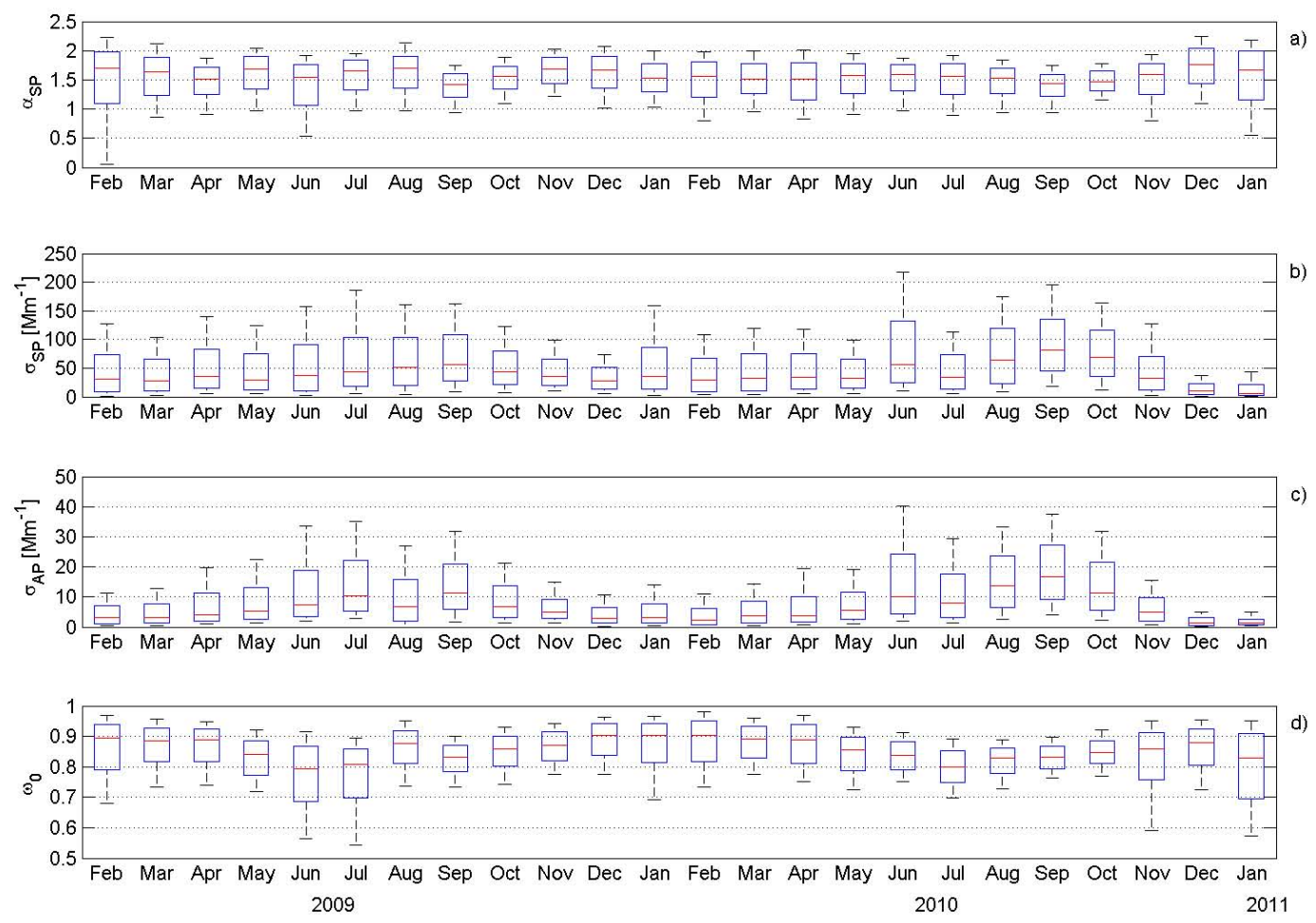

Fig. 8. Aerosol optical parameters at Elandsfontein: (a) Ångström exponent of scattering $(\lambda=450 \ldots 635 \mathrm{~nm})$, (b) scattering coefficient $(\lambda=637 \mathrm{~nm}),(\mathbf{c})$ absorption coefficient $(\lambda=637 \mathrm{~nm})$, and (d) single-scattering albedo $(\lambda=637 \mathrm{~nm})$ for particle diameters $<10 \mu \mathrm{m}$ for the period 11 February 2009-31 January 2011. The red lines represent the 50\% percentile, the blue boxes the 25 and $75 \%$ percentiles and the black whiskers the 5 and $95 \%$ percentiles.

Finally, the Elandsfontein aerosol optical data is put in a global perspective. The average scattering and absorption coefficients are compared with respective published results from some other sites by plotting the averages and standard deviations in a scatter plot (Fig. 10). Delene and Ogren (2002) presented aerosol optical data from several North American sites. Three of these sites, Barrow, Alaska (representing a background site), the Southern Great Plains Station (SGP), Oklahoma (representing a continental site), and the anthropogenically influenced site Bondville, Illinois (BND) are referenced. Delene and Ogren (2002) presented $\sigma_{\mathrm{SP}}$ and $\sigma_{\mathrm{AP}}$ at $\lambda=550$ and the average $\alpha_{\mathrm{SP}}$. Using this, $\sigma_{\mathrm{SP}}$ was interpolated to $637 \mathrm{~nm}$. For absorption, the Ångström exponent of 1 was assumed and and $\sigma_{\mathrm{AP}}$ at $550 \mathrm{~nm}$ was extrapolated to $637 \mathrm{~nm}$. Two European stations were also included in the comparison plot. Lyamani et al. (2008) measured scattering and absorption at an urban site in Granada, Spain. They also presented average $\sigma_{\mathrm{SP}}$ at $550 \mathrm{~nm}$ and $\alpha_{\mathrm{SP}}$, so similar interpolation to $637 \mathrm{~nm}$ could be done. They measured absorption with a MAAP so their $\sigma_{\mathrm{AP}}$ was used as such. Virkkula et al. (2011) presented aerosol optical data measured at the boreal forest site of SMEAR II in Finland. In this paper both scattering and absorption and respective Ångström exponents were presented at three wavelengths so they were interpolated to $637 \mathrm{~nm}$. As the most polluted sites the Pearl River Delta and the North China Plain in China were selected (Garland et al., 2008, 2009). Garland et al. $(2008,2009)$ presented average $\sigma_{\mathrm{SP}}$ at three wavelengths and $\alpha_{\mathrm{SP}}$, so the interpolation to $637 \mathrm{~nm}$ could be done. They presented $\sigma_{\mathrm{AP}}$ at $532 \mathrm{~nm}$. It was extrapolated to $637 \mathrm{~nm}$ using the Ångström exponent of 1 .

The conclusion of the scatter plot (Fig. 10) is that Elandsfontein is a polluted continental site, as far as scattering and absorption are concerned. However, it is cleaner than highly polluted regional sites, especially in China. To quantify this, the ratios of the average scattering and absorption coefficients at the sites shown in Fig. 10, to those at Elandsfontein were calculated. They are 5.9 and 5.2 for Beijing, 3.2 and 4.3 for Guanzhou, 1.3 and 3.4 for Granada, 0.85 and 0.46 for Bondville, 0.72 and 0.25 for Lamont, 0.28 and 0.21 for Hyytiälä, and 0.17 and 0.04 at Barrow.

\subsection{Relationships between particle and sulphur dioxide concentrations}

A simple study on the source of particles was done by comparing aerosol number concentrations, aerosol volume concentrations and sulphur dioxide concentrations (Fig. 11). There is a positive correlation between aerosol number concentrations and aerosol volume concentration, but the spread 

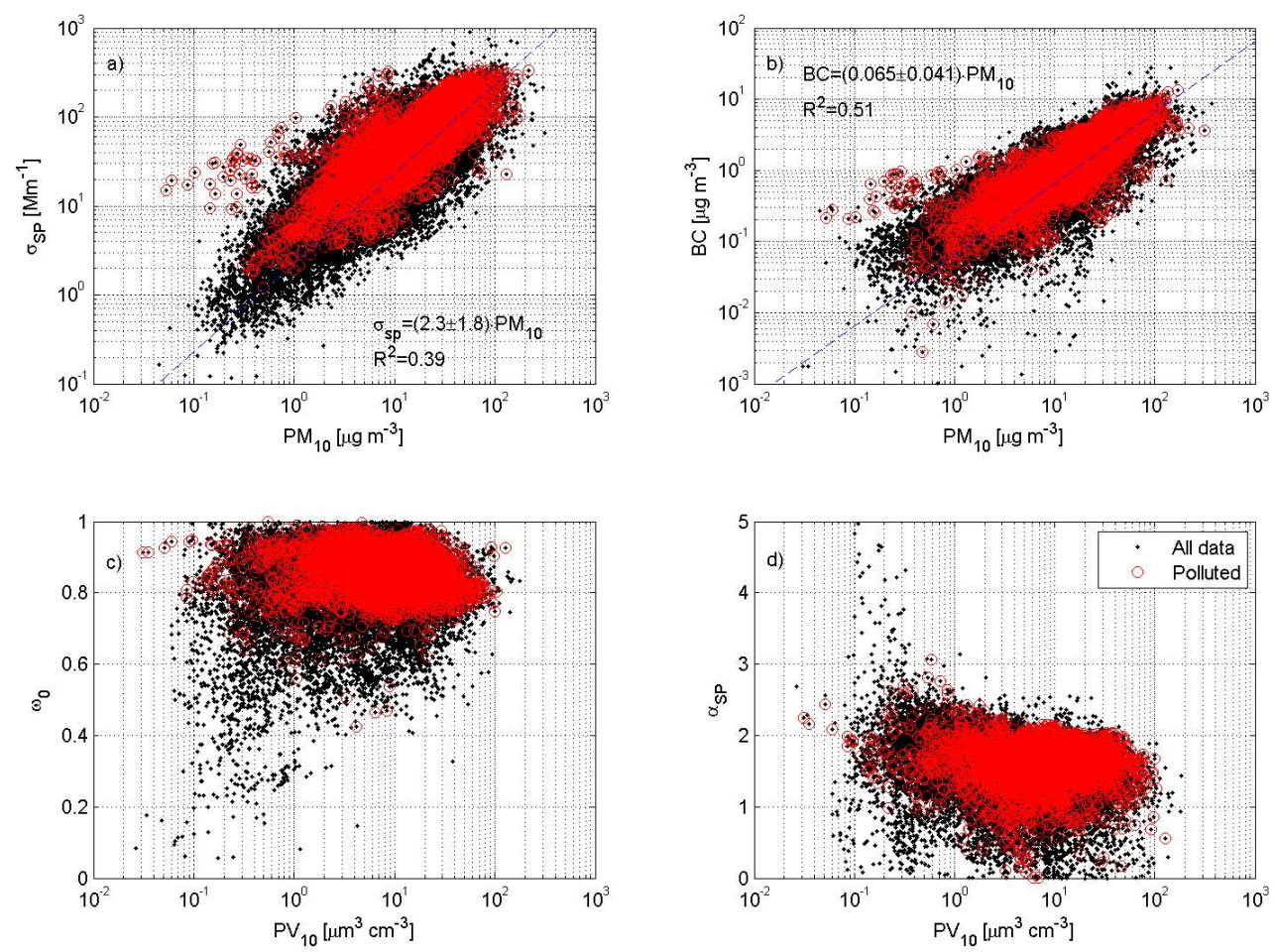

Fig. 9. Relationships between aerosol optical parameters and integrated volume or mass concentration. (a) Scattering coefficient $\sigma_{\mathrm{SP}}$ vs. $\mathrm{PM}_{10}$ mass concentration calculated from the $\mathrm{PM}_{10}$ volume concentration assuming the particle density $1.5 \mathrm{~g} \mathrm{~cm}^{-3}$. The error value of the slope is the standard deviation obtained from a linear regression of scattering versus $\mathrm{PM}_{10}$, (b) black carbon concentration $m(\mathrm{BC})$ vs. $\mathrm{PM}_{10}$ mass concentration calculated from the $\mathrm{PM}_{10}$ volume concentration assuming the particle density $1.7 \mathrm{~g} \mathrm{~cm}^{-3}$. The error value of the slope is the standard deviation calculated as in (a, c) single scattering albedo as a function $\mathrm{PV}_{10}$ concentration, and (d) Ångström exponent as a function $\mathrm{PV}_{10}$ concentration.

of the data is very large: for instance number concentrations of $10^{4} \mathrm{~cm}^{-3}$ were observed both in very clean air with $\mathrm{PV}_{10}<1 \mu \mathrm{m}^{3} \mathrm{~cm}^{-3}$ and in highly polluted air with $\mathrm{PV}_{10} \sim$ $100 \mu^{3} \mathrm{~cm}^{-3}$ (Fig. 11a). The highest number concentrations, larger than $\sim 4 \times 10^{4} \mathrm{~cm}^{-3}$ were observed at volume concentrations of $\sim 10 \mathrm{\mu m}^{3} \mathrm{~cm}^{-3}$ instead of higher volume concentrations. This suggests highest number concentrations resulting from nucleation in cases with relatively high $\mathrm{SO}_{2}$, but moderate condensation and coagulation sinks by the preexisting particles.

The main source of sulphur dioxide $\left(\mathrm{SO}_{2}\right)$ in this region is industry. $\mathrm{SO}_{2}$ is oxidized in the atmosphere to sulphuric acid that forms particles by nucleation or condenses on preexisting particles. The nucleation explains the clear positive relationship between $\mathrm{SO}_{2}$ and particle number concentrations (Fig. 11b). The relationship between $\mathrm{SO}_{2}$ and aerosol volume concentration is not so clear but one thing is obvious: the highest volume concentrations, close to $100 \mu \mathrm{m}^{3} \mathrm{~cm}^{-3}$ were not observed at the highest $\mathrm{SO}_{2}$ concentrations of larger than $50 \mathrm{ppb}$ but at concentrations of $\sim 1 \mathrm{ppb}$ (Fig. 11c). This supports the above-mentioned interpretation that the high aerosol volume concentrations were in aged pollution plumes.
One more point is worth mentioning in Fig. 11. The main source of $\mathrm{SO}_{2}$ in the region is industry, but it can be seen that there is no obvious difference between the $\mathrm{SO}_{2}$ concentration distribution in the data classified as polluted and the rest of the data. This supports further the explanation that there are high uncertainties in the back trajectories and/or in the emission inventories. The latter is not impossible, since an open access, peer reviewed emission inventory database is not currently available in South Africa.

\section{Conclusions}

A large number of long-term aerosol measurements are carried out in the Northern Hemisphere while measurements are sparse in the Southern Hemisphere. Due to the limited number of measurements, results from global models are not compared or validated. This hampers the evaluation of climate scenarios and development of climate change mitigation plans. This knowledge gap was partially addressed during this study of one of the Southern Hemisphere pollution hotspots.

The concentrations of industrially related trace gases were within a global context (Carmichael et al., 2003) relatively 


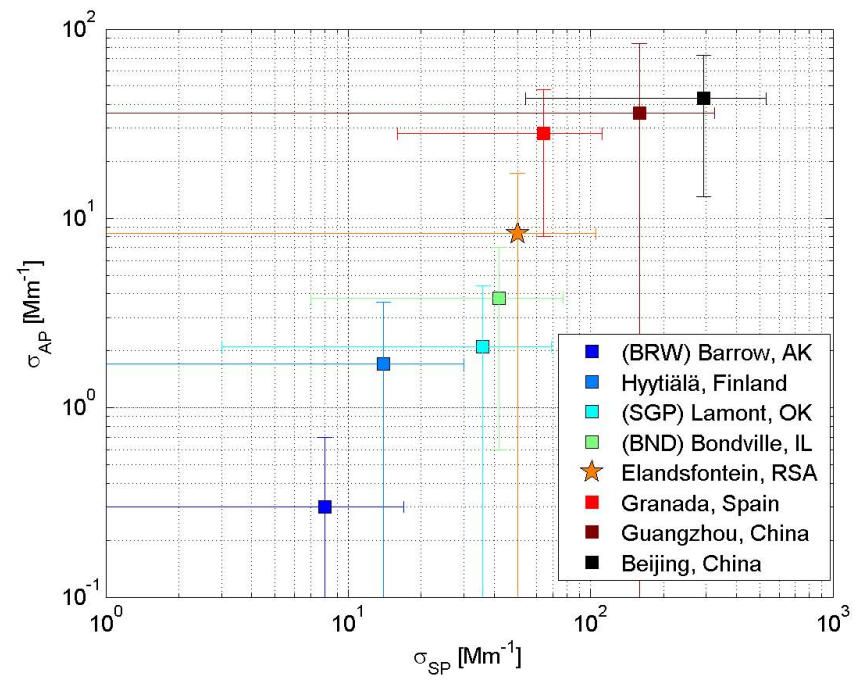

Fig. 10. Absorption coefficient as a function of scattering coefficient for different location: Barrow, USA (Delene and Ogren, 2002), Hyytiälä, Finland (Virkkula et al., 2011), Lamont, USA (Delene and Ogren, 2002), Bondville, USA (Delene and Ogren, 2002), Elandsfontein, South Africa (this study), Granada, Spain (Lyamani et al., 2008), Guangzhou, China (Garland et al., 2008), Beijing, China (Garland et al., 2009). Error bars represent standard deviation, negative values are not shown.

high; with $\mathrm{NO}_{2}$ and $\mathrm{SO}_{2}$ sometimes exceeding the South African AQ standards, but the major concern was found to be the high regional ozone levels. $\mathrm{O}_{3}$ is a secondary pollutant, implying that emissions of $\mathrm{O}_{3}$-percursors (e.g. $\mathrm{NO}_{2}$, VOCs and $\mathrm{CO}$ ) have to be addressed to rectify the problem.

The aerosol data showed annual cycle of aerosol optical parameters clearly related to both emission sources such as industry, wildfires, and biogenic sources, and meteorology. Both scattering and absorption coefficients were highest in the Southern Hemisphere winter and spring (June-October) and lowest in summer and autumn (December-March). The contribution of anthropogenic emissions and wildfires to the total extinction is to be studied together with the chemical composition in forthcoming papers.

In global context, the average aerosol scattering and absorption values are typical of an anthropogenically influenced continental site, but below that of the highly polluted areas of e.g. China. For example, published average scattering and absorption coefficients in Guangzhou and Beijing are about 3 to 6 times higher than at Elandsfontein.

The measurements reported in this paper represent the longest published data series of absorption and scattering of the continental southern African aerosol at the surface level. The preliminary results presented here, will be augmented in future by detailed optical studies incorporating the groundbased measurements with Lidar and satellite observations. It will be important also to use the data in combination with the AERONET measurements that provide column-averaged information on aerosol optical properties. It is worth noting al-
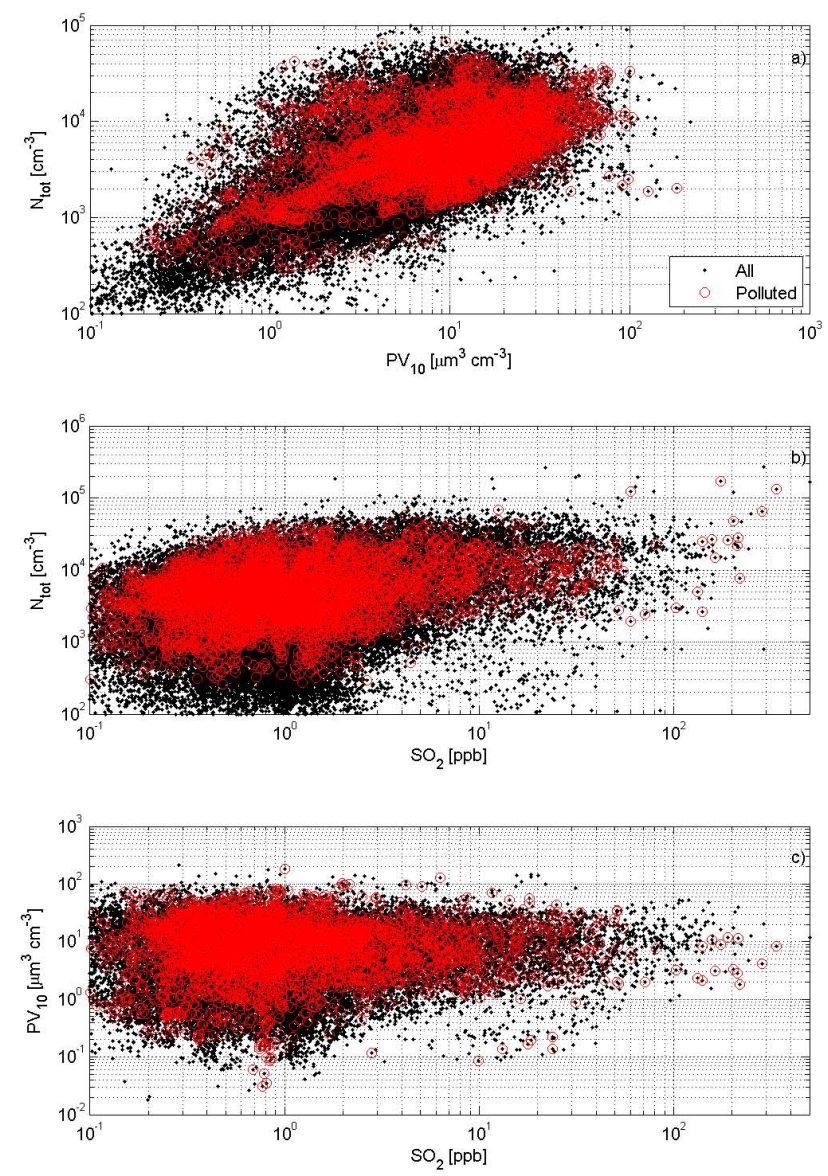

Fig. 11. Relationships between particle number, volume, and $\mathrm{SO}_{2}$ concentrations. (a) $N_{\text {tot }}$ as a function of $\mathrm{PV}_{10}$, (b) $N_{\text {tot }}$ as a function of $\mathrm{SO}_{2}$, and (c) $\mathrm{PV}_{10}$ as a function of $\mathrm{SO}_{2}$.

ready at this point that the single-scattering albedo retrieved from the AERONET data at the South African site Skukuza was $0.90 \pm 0.03$ (Queface et al., 2011), clearly higher than that at the ground level during this work, $0.84 \pm 0.08$. This suggests that the most absorbing aerosols are in the lower layers of the atmosphere, which may have implications to modeling the columnar aerosol optics. Further studies are needed to confirm or reject this. Estimates on the aerosol direct radiative forcing in the region will also be made. In addition, the data gathered during this project will provide the global modelling community a reference point on regional background of the largest industrial area in Africa.

Acknowledgements. This work was funded by the by European Commission 6th Framework programme project EUCAARI (036833-2), Academy of Finland (117505, 132640, 211483, 211484, 1118615), European Research Council (ATMNUCLE), Vilho, Yrjö and Kalle Väisälä foundation and Saastamoinen foundation. Logistical, financial and on-site support was also provided by Eskom ltd and Sasol ltd.

Edited by: K. Carslaw 


\section{References}

Andrews, E., Ogren, J. A., Bonasoni, P., Marinoni, A., Cuevas, E., Rodríguez, S., Sun, J. Y., Jaffe, D. A., Fischer, E. V., Baltensperger, U., Weingartner, E., Coen Collaud, M., Sharma, S., Macdonald, A. M., Leaitch, W. R., Lin, N.-H., Laj, P., Arsov, T., Kalapov, I., Jefferson, A., and Sheridan, P.: Climatology of aerosol radiative properties in the free troposphere, Atmos. Res., 104, 365-393, doi:10.1016/j.atmosres.2011.08.017, 2011.

Ångström, A.: On the atmospheric transmission of sun radiation and on dust in the air, Geogr. Ann., 11, 156-166, doi:10.2307/519399, 1929.

Althausen, D., Engelmann, R., Baars, H., Heese, B., Ansmann, A., Müller D., and Komppula, M.: Portable Raman lidar PollyXT for automated profiling of aerosol backscatter, extinction, and depolarization, J. Atmos. Ocean. Tech., 26, 2366-2378, doi:10.1175/2009JTECHA1304.1, 2009.

Beirle, S., Kühl, S., Pukite, J., and Wagner, T.: Retrieval of tropospheric column densities of $\mathrm{NO}_{2}$ from combined SCIAMACHY nadir/limb measurements, Atmos. Meas. Tech., 3, 283299, doi:10.5194/amt-3-283-2010, 2010.

Birch, M. E. and Cary, R. A.: Elemental carbon-based method for monitoring occupational exposures to particulate diesel exhaust, Aerosol Sci. Technol., 25, 221-241, 1996.

Brunke, E.-G., Labuschagne, C., Ebinghaus, R., Kock, H. H., and Slemr, F.: Gaseous elemental mercury depletion events observed at Cape Point during 20072008, Atmos. Chem. Phys., 10, 11211131, doi:10.5194/acp-10-1121-2010, 2010.

Cardoso, A. A., Liu, H., and Dasgupta, P. K.: Fluorometric fiber optic drop sensor for atmospheric hydrogen sulphide, Talanta, 44, 1099-1106, 1997.

Carmichael, G., Ferm, M., Thongboonchooa, N., Woo, J., Chan, L. Y., Murano, K., Viet, P., Mossberg, C., Bala, R., Boonjawat, J., Upatum, P., Mohan, M., Adhikary, S., Shrestha, A., Pienaar, J., Brunke, E., Chen, T., Jie, T., Guoan, D., Peng, L., Dhiharto, S., Harjanto, H., Jose, A., Kimani, W., Kirouane, A., Lacaux, J.P., Richard, S., Barturen, O., Cerda, J., Athayde, A., Tavares, T., Cotrina, J., and Bilici, E.: Measurements of sulfur dioxide, ozone and ammonia concentrations in Asia, Africa, and South America using passive samplers, Atmos. Environ., 37, 1293-1308, 2003.

Carruthers, V.: Wildlife of Southern Africa, Struik publishers, Cape Town, 1997.

Cavalli, F., Viana, M., Yttri, K. E., Genberg, J., and Putaud, J.P.: Toward a standardised thermal-optical protocol for measuring atmospheric organic and elemental carbon: the EUSAAR protocol, Atmos. Meas. Tech., 3, 79-89, doi:10.5194/amt-3-79-2010, 2010.

Center for International Earth Science Information Network (CIESIN), Columbia University, United Nations Food and Agriculture Programme (FAO), and Centro Internacional de Agricultura Tropical (CIAT), 2005, Gridded Population of the World: Future Estimates (GPWFE), Palisades, NY: Socioeconomic Data and Applications Center (SEDAC), Columbia University, available at: http://sedac.ciesin.columbia.edu/gpw, 2010.

Betts, A. K. and Ball, J. H.: Albedo over the boreal forest, J. Geophys. Res., 102, 28901-28909, doi:10.1029/96JD03876, 1997.

Charlson, R. J., Ahlquist, N. C., and Horvath, H.: On the generality of correlation of atmospheric aerosol mass concentration and light scatter, Atmos. Environ., 2, 455-464, 1967.

Collett, K. S., Piketh, S. J., and Ross, K. E.: An assessment of the atmospheric nitrogen budget on the South African Highveld, South Afr. J. Sci., 106, doi:10.4102/sajs.v106i5/6.220, 2010.

Delene, D. J. and Ogren, J. A.: Variability of aerosol optical properties at four North American surface monitoring sites, J. Atmos. Sci., 59, 1135-1150, 2002.

Eck, T. F., Holben, B. N.,Ward, D. E., Mukelabai, M. M., Dubovik, O., Smirnov, A., Schafer, J. S., Hsu, N. C., Piketh, S. J., Queface, A., Le Roux, J., and Slutsker, I.: Variability of biomass burning aerosol optical characteristics in southern Africa during the SAFARI 2000 dry season campaign and a comparison of single scattering albedo estimates from radiometric measurements, J. Geophys. Res., 108, 8477, doi:10.1029/2002JD002321, 2003.

Draxler R. R. and Hess, G. D.: Description of the HYSPLIT_4 Modeling System, NOAA Technical Memorandum ERL ARL-224, 2004.

Fleming, G. and van der Merwe, M.: Spatial Disaggregation of Greenhouse Gas Emission Inventory Data for Africa South of the Equator, available at: http://gis.esri.com/library/ userconf/proc00/professional/papers/PAP896/p896.htm (last access: February 2012), 2004.

Forster, P., Ramaswamy, V., Artaxo, P., Berntsen, T., Betts, R., Fahey, D. W., Haywood,J., Lean, J., Lowe, D. C., Myhre, G., Nganga, J., Prinn, R., Raga, G., Schulz, M., and Van Dorland, R.: Changes in Atmospheric Constituents and in Radiative Forcing, in: Climate Change 2007: The Physical Science Basis. Contribution of Working Group I to the Fourth Assessment Report of the Intergovernmental Panel on Climate Change, edited by: Solomon, S., Qin, D., Manning, M., Chen, Z., Marquis, M., Averyt, K. B., Tignor, M., and Miller, H. L., Cambridge University Press, Cambridge, United Kingdom and New York, NY, USA, 2007.

Freiman, M. T. and Piketh, S. J.: Air transport into and out of the Industrial Highveld Region of South Africa, J. Appl. Meteorol., 42, 994-1002, 2002.

Garland, R. M., Yang, H., Schmid, O., Rose, D., Nowak, A., Achtert, P., Wiedensohler, A., Takegawa, N., Kita, K., Miyazaki, Y., Kondo, Y., Hu, M., Shao, M., Zeng, L. M., Zhang, Y. H., Andreae, M. O., and Pöschl, U.: Aerosol optical properties in a rural environment near the mega-city Guangzhou, China: implications for regional air pollution, radiative forcing and remote sensing, Atmos. Chem. Phys., 8, 5161-5186, doi:10.5194/acp-85161-2008, 2008.

Garland, R. M., Schmid, O., Nowak, A., Achtert, P., Wiedensohler, A., Gunthe, S. S., Takegawa, N., Kita, K., Kondo, Y., Hu, M., Shao, M., Zeng, L. M., Zhu, T., Andreae, M. O., and Pöschl, U.: Aerosol optical properties observed during Campaign of Air Quality Research in Beijing 2006 (CAREBeijing2006): Characteristic differences between the inflow and outflow of Beijing city air, J. Geophys. Res., 114, D00G04, doi:10.1029/2008JD010780, 2009.

Garstang, M., Tyson, M., Swap, R., Edwards, M., Kållberg, P., and Lindesay, J. A.: Horizontal and vertical transport of air over southern Africa, J. Geophys. Res., 101, 23721-23736, 1996.

Gilardoni, S., Liu, S., Takahama, S., Russell, L. M., Allan, J. D., Steinbrecher, R., Jimenez, J. L., De Carlo, P. F., Dunlea, E. J., and Baumgardner, D.: Characterization of organic ambient aerosol during MIRAGE 2006 on three platforms, Atmos. Chem. Phys., 9, 5417-5432, doi:10.5194/acp-9-5417-2009, 2009.

Gilardoni, S., Vignati, E., Marmer, E., Cavalli, F., Belis, C., Gi- 
anelle, V., Loureiro, A., and Artaxo, P.: Sources of carbonaceous aerosol in the Amazon basin, Atmos. Chem. Phys., 11, 27472764, doi:10.5194/acp-11-2747-2011, 2011.

Guyon, P., Graham, B., Beck, J., Boucher, O., Gerasopoulos, E., Mayol-Bracero, O. L., Roberts, G. C., Artaxo, P., and Andreae, M. O.: Physical properties and concentration of aerosol particles over the Amazon tropical forest during background and biomass burning conditions, Atmos. Chem. Phys., 3, 951-967, doi:10.5194/acp-3-951-2003, 2003.

Hand, J. L. and W. C. Malm: Review of aerosol mass scattering efficiencies fromground-basedmeasurements since 1990. J. Geophys. Res., 112, D16203, doi:10.1029/2007JD008484, 2007.

Hansen, J., Sato, M., Ruedy, R., Kharecha, P., Lacis, A., Miller, R. L., Nazarenko, L., Lo, K., Schmidt, G. A., Russell, G., Aleinov, I., Bauer, S., Baum, E., Cairns, B., Canuto, V., Chandler, M., Cheng, Y., Cohen, A., Del Genio, A., Faluvegi, G., Fleming, E., Friend, A., Hall, T., Jackman, C., Jonas, J., Kelley, M., Kiang, N. Y., Koch, D., Labow, G., Lerner, J., Menon, S., Novakov, T., Oinas, V., Perlwitz, J. P., Perlwitz, J., Rind, D., Romanou, A., Schmunk, R., Shindell, D., Stone, P., Sun, S., Streets, D., Tausnev, N., Thresher, D., Unger, N., Yao, M., and Zhang, S.: Climate simulations for 1880-2003 with GISS modelE, Clim. Dynam., 29, 661-696, doi:10.1007/s00382-007-0255-8, 2007.

Haywood, J. M. and Boucher, O. Estimates of the direct and indirect radiative forcing due to tropospheric aerosols: A Review, Rev. Geophys, 38, 513-543, 2000.

Haywood, J. M. and Shine, K. P.: The effect of anthropogenic sulfate and soot aerosol on the clear sky planetary radiation budget, Geophys. Res. Lett., 22, 603-606, 1995.

Held, G., Scheifinger, H., Snyman, G. M., Tosen, G. R., and Zunckel, M.: The Climatology and Meteorology of the Highveld, in: Air pollution and its impacts on the South African Highveld, edited by: Held, G., Gore, B. J., Surridge, A. D., Tosen, G. R., Turner, C. R., and Walmsey, R. D., Environmental Scientific Association Cleveland, 1996.

Hirsikko, A., Vakkari, V., Tiitta, P., Manninen, H. E., Gagné, S., Laakso, H., Kulmala, M., Mirme, A., Mirme, S., Mabaso, D., Beukes, J. P., and Laakso, L.: Characterisation of submicron particle number concentrations and formation events in the western Bushveld Igeneous Complex, South Africa, Atmos. Chem. Phys. Discuss., 12, 1895-1934, doi:10.5194/acpd-121895-2012, 2012.

Holben, B. N., Eck, T. F., Slutsker, I., Tanre, D., Buis, J. P., Setzer, A., Vermote, E., Reagan, J. A., Kaufman, Y., Nakajima, T., Lavenu, F., Jankowiak, I., and Smirnov, A.: AERONET - A federated instrument network and data archive for aerosol characterization, Remote Sens. Environ., 66, 1-16, 1998.

Jayaratne, E. R. and Verma, T. S.: The impact of biomass burning on the environmental aerosol concentration in Gaborone, Botswana, Atmos. Environ., 35, 1821-1828, 2001.

Josipovic, M., Annegarn, H. J., Kneen, M. A., Pienaar, J. J., and Piketh, S. J.: Concentrations, Distributions and Critical Levels Exceedance Assessment of $\mathrm{SO}_{2}, \mathrm{NO}_{2}$ and $\mathrm{O}_{3}$ in South Africa, Environ. Monit. Assess., 171, 181-196, 2010.

Kulmala, M., Asmi, A., Lappalainen, H. K., Carslaw, K. S., Pöschl, U., Baltensperger, U., Hov, Ø., Brenquier, J.-L., Pandis, S. N., Facchini, M. C., Hansson, H.-C., Wiedensohler, A., and O'Dowd, C. D.: Introduction: European Integrated Project on Aerosol Cloud Climate and Air Quality interactions (EUCAARI)
- integrating aerosol research from nano to global scales, Atmos. Chem. Phys., 9, 2825-2841, doi:10.5194/acp-9-2825-2009, 2009.

Laakso, L., Koponen, I. K., Mönkkönen, P., Kulmala, M., Kerminen, V.-M., Wehner, B., Wiedensohler, A., Wu, Z., and Hu, M.: Aerosol particles in the developing world; a comparison between New Delhi in India and Beijing in China, Water Air Soil Pollut., 173, 1-16, doi:10.1007/s11270-005-9018-5, 2006.

Laakso, L., Laakso, H., Aalto, P. P., Keronen, P., Petäjä, T., Nieminen, T., Pohja, T., Siivola, E., Kulmala, M., Kgabi, N., Molefe, M., Mabaso, D., Phalatse, D., Pienaar, K., and Kerminen, V.-M.: Basic characteristics of atmospheric particles, trace gases and meteorology in a relatively clean Southern African Savannah environment, Atmos. Chem. Phys., 8, 4823-4839, doi:10.5194/acp-8-4823-2008, 2008.

Laakso, L., Merikanto, J., Vakkari, V., Laakso, H., Kulmala, M., Molefe, M., Kgabi, N., Mabaso, D., Carslaw, K., Spracklen, D. V., and Kerminen, V.-M.: Boundary layer nucleation as a source of new CCN in savannah environment, Atmos. Chem. Phys. Discuss., submitted, 2012.

Leahy, L. V., Anderson, T. L., Eck, T. F., and Bergstrom, R. W.: A synthesis of single scattering albedo of biomass burning aerosol over southern Africa during SAFARI 2000, Geophys. Res., Lett., 34, L12814, doi:10.1029/2007GL029697, 2007.

Lourens, A. S. M., Beukes, J. P., Van Zyl, P. G., Fourie, G. D., Burger, J. W., Pienaar, J. J., Read, C. E., and Jordaan, J. H.: Spatial and temporal assessment of gaseous pollutants in the Highveld of South Africa, S. Afr. J. Sci., 107, 8 pp., 2011.

Lourens, A. S. M., Butler, T. M., Beukes, J. P., Van Zyl, P. G., Beirle, S., Wagner, T., Heue, K.-P., Pienaar, J. J., Fourie, G. D., and Lawrence, M. G.: Re-evaluating the $\mathrm{NO}_{2}$ hotspot over the South African Highveld, S. Afr. J. Sci., accepted, 2012.

Logan, D.: Upgrading an Aurora 1000 or 3000 Nephelometer with an Opal Glass Light Source, Ecotech technical notes, 52, 2009.

Lyamani, H., Olmo, F. J., and Alodo-Arboleda, L.: Light scattering and absorption properties of aerosol particles in the urban environment of Granada, Spain, Atmos. Environ., 42, 2630-2642, 2008.

Malm, W. C. and Hand, J. L.: An examination of the physical and optical properties of aerosols collected in the IMPROVE program, Atm. Environ., 41, 3407-3427, 2007.

Martins, J. J., Dhammapala, R. S., Lachmann, G., Galy-Lacaux, C., and Pienaar, J. J.: Long-term measurements of sulphur dioxide, nitrogen dioxide, ammonia, nitric acid and ozone in southern Africa using passive samplers, S. Afr. J. Sci., 103, 336-342, 2007.

Mikhailov, E., Vlasenko, S., Podgorny, I., Ramanathan, V., and Corrigan, C.: Optical properties of soot-water drop agglomerates: An experimental study, J. Geophys. Res., 111, 1-16, 2006.

Müller, T., Laborde, M., Kassell, G., and Wiedensohler, A.: Design and performance of a three-wavelength LED-based total scatter and backscatter integrating nephelometer, Atmos. Meas. Tech., 4, 1291-1303, doi:10.5194/amt-4-1291-2011, 2011.

National Environmental Management Air (NEMA) Quality Act of 2004 section 63. C2004. Government Gazette Republic of South Africa, 24 December 2009, 534, 8-9, available at: www.info. gov.za, 2009.

Notice of intention to declare the Highveld Priority Area in terms of Section 18(1) of the National Environmental Management: Air 
Quality Act, 2004, Act no. 39 of 2004, Proclamation no. 396, 2007.

Parrish, D., Singh, H., Molina, L., and Madronich, S.: Air quality progress in North American megacities: A review, Atmos. Environ., 45, 7015-7025, doi:10.1016/j.atmosenv.2011.09.039, 2011.

Petzold, A. and Schönlinner, M.: Multi-angle absorption photometry - a new method for the measurement of aerosol light absorption and atmospheric black carbon, J. Aerosol Sci., 35, 421-441, 2004.

Piketh, S., Tyson, P., and Steffen, W.: Aeolian transport from southern Africa and iron fertilization of marine biota in the South Indian Ocean, S. Afr. J. Sci., 96, 244-246, 2000.

Putaud, J.-P., Van-Dingenen, R., and Raes, F.: Submicron aerosol mass balance at urban and semirural sites in the Milan area (Italy), J. Geophys. Res., 107, 8198, doi:10.1029/2000JD000111, 2002.

Queface, A. J., Piketh, S. J., Eck, T. F., Tsay, S.-C., and Mavume, A. F.: Climatology of aerosol optical properties in Southern Africa, Atmos. Environ., 45, 2910-2921, 2011.

Rissler, J., Vestin, A., Swietlicki, E., Fisch, G., Zhou, J., Artaxo, P., and Andreae, M. O.: Size distribution and hygroscopic properties of aerosol particles from dry-season biomass burning in Amazonia, Atmos. Chem. Phys., 6, 471-491, doi:10.5194/acp6-471-2006, 2006.

Ross, K. E., Piketh, S. J., Bruintjes, R. T., Burger, R. P., Swap, R. J., and Annegarn, H. J.: Spatial and seasonal variations in CCN distribution and the aerosol-CCN relationship over southern Africa, J. Geophys. Res., 108, 8481, doi:10.1029/2002JD002384, 2003.

SAWS, available at: http://www.weathersa.co.za/Climat/Climstats/ BethalStats.jsp (last access: April 2010), 2009.

Schuster, G. L., Dubovik, O., and Holben, B. N.: Angstrom exponent and bimodal aerosol size distributions, J. Geophys. Res., 111, D07207, doi:10.1029/2005JD006328, 2006.

Sillman, S.: The relation between ozone, NOx and hydrocarbons in urban and polluted rural environments, Atmos. Environ., 33, 1821-1845, 1999.

Suni, T., Kulmala, M., Hirsikko, A., Bergman, T., Laakso, L., Aalto, P. P., Leuning, R., Cleugh, H., Zegelin, S., Hughes, D., van Gorsel, E., Kitchen, M., Vana, M., Hõrrak, U., Mirme, S., Mirme, A., Sevanto, S., Twining, J., and Tadros, C.: Formation and characteristics of ions and charged aerosol particles in a native Australian Eucalypt forest, Atmos. Chem. Phys., 8, 129-139, doi:10.5194/acp-8-129-2008, 2008.

Swap, R. J., Annegarn, H. J., Suttles, J. T., King, M. D., Platnick, S., Privette, J. L., and Scholes, R. J.: Africa burning: A thematic analysis of the Southern African Regional Science Initiative (SAFARI 2000), J. Geophys. Res., 108, 8465, doi:10.1029/2003JD003747, 2003.

Toenges-Schuller N., Stein, O., Rohrer, F., Wahner, A., Richter, A., Burrows, J. P., Beirle, S., Wagner, T., Platt, U., and Elvidge, C. D.: Global distribution pattern of anthropogenic nitrogen oxide emissions: Correlation analysis of satellite measurements and model calculations, J. Geophys. Res., 111, D05312, doi:10.1029/2005JD006068, 2006.

Tuch, T. M., Haudek, A., Müller, T., Nowak, A., Wex, H., and Wiedensohler, A.: Design and performance of an automatic regenerating adsorption aerosol dryer for continuous operation at monitoring sites, Atmos. Meas. Tech., 2, 417-422, doi:10.5194/amt-2-417-2009, 2009.
Tyson, P. D. and Preston-Whyte, R. A.: The Weather and Climate of Southern Africa, Oxford University Press, 408 pp., 2000.

Tyson, P. D., Garstang, M., and Swap, R.: Large-scale recirculation of Air over Southern Africa, J. Appl. Meteorol., 35, 2218-2236, 1996.

Vaisala, available at: http://www.campbellsci.com/wxt510, cited: 1 April 2010.

Vakkari, V., Laakso, H., Kulmala, M., Laaksonen, A., Mabaso, D., Molefe, M., Kgabi, N., and Laakso, L.: New particle formation events in semi-clean South African savannah, Atmos. Chem. Phys., 11, 3333-3346, doi:10.5194/acp-11-3333-2011, 2011.

Venter, A. D., Vakkari, V., Beukes, J. P., van Zyl, P. G., Laakso, H., Mabaso, D., Tiitta, P., , Josipovic, M., Kulmala, M., Pienaar, J. J., and Laakso, L.: An air quality assessment in the industrialised western Bushveld Igneous Complex, South Africa, S. Afr. J. Sci., submitted, 2012.

Virkkula, A.: Correction of the calibration of the 3-wavelength Particle Soot Absorption Photometer ( $3 \lambda$ PSAP), Aerosol Sci. Technol., 44, 706-712, 2010.

Virkkula, A., Ahlquist, N. C., Covert, D. S., Arnott, W. P., Sheridan, P. J., Quinn, P. K., and Coffman, D. J.: Modification, Calibration and a Field Test of an Instrument for Measuring Light Absorption by Particles, Aerosol Sci. Technol., 39, 68-83, 2005.

Virkkula, A., Backman, J., Aalto, P. P., Hulkkonen, M., Riuttanen, L., Nieminen, T., dal Maso, M., Sogacheva, L., de Leeuw, G., and Kulmala, M.: Seasonal cycle, size dependencies, and source analyses of aerosol optical properties at the SMEAR II measurement station in Hyytiälä, Finland, Atmos. Chem. Phys., 11, 4445-4468, doi:10.5194/acp-11-4445-2011, 2011.

Wiedensohler, A., Birmili, W., Nowak, A., Sonntag, A., Weinhold, K., Merkel, M., Wehner, B., Tuch, T., Pfeifer, S., Fiebig, M., Fjäraa, A. M., Asmi, E., Sellegri, K., Depuy, R., Venzac, H., Villani, P., Laj, P., Aalto, P., Ogren, J. A., Swietlicki, E., Roldin, P., Williams, P., Quincey, P., Hüglin, C., Fierz-Schmidhauser, R., Gysel, M., Weingartner, E., Riccobono, F., Santos, S., Grning, C., Faloon, K., Beddows, D., Harrison, R. M., Monahan, C., Jennings, S. G., O’Dowd, C. D., Marinoni, A., Horn, H.-G., Keck, L., Jiang, J., Scheckman, J., McMurry, P. H., Deng, Z., Zhao, C. S., Moerman, M., Henzing, B., and de Leeuw, G.: Particle mobility size spectrometers: harmonization of technical standards and data structure to facilitate high quality long-term observations of atmospheric particle number size distributions, Atmos. Meas. Tech. Discuss., 3, 5521-5587, doi:10.5194/amtd-3-55212010, 2010.

Wenig, M., Spichtinger, N., Stohl, A., Held, G., Beirle, S., Wagner, T., Jhne, B., and Platt, U.: Intercontinental transport of nitrogen oxide pollution plumes, Atmos. Chem. Phys., 3, 387-393, doi:10.5194/acp-3-387-2003, 2003.

Zunckel, M., Koosailee, A. Yarwood, G., Maure, G., Venjonoka, K., van Tienhoven, A. M., and Otter, L.: Modelled surface ozone over southern Africa during the Cross Border Air Pollution Impact Assessment Project, Environ. Modell. Softwa., 21, 911-924, 2005. 